
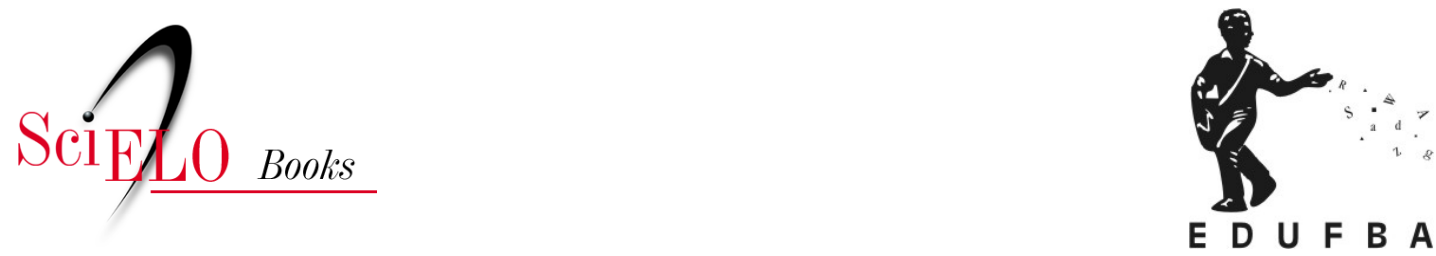

\title{
A solidariedade: um inconsciente da teoria das organizações?
}

\author{
Genauto Carvalho de França Filho \\ Philippe Eynaud
}

\section{SciELO Books / SciELO Livros / SciELO Libros}

FRANÇA FILHO, G. C., and EYNAUD, P. A solidariedade: um inconsciente da teoria das organizações?. In.: Solidariedade e organizações: pensar uma outra organização [online]. Salvador: EDUFBA; Ateliê de Humanidades, 2020, pp. 21-70. ISBN: 978-65-5630-199-0. https://doi.org/10.7476/9786556301990.0002.

\section{(c) (1)}

All the contents of this work, except where otherwise noted, is licensed under a Creative Commons Attribution 4.0 International license.

Todo o conteúdo deste trabalho, exceto quando houver ressalva, é publicado sob a licença Creative Commons Atribição 4.0.

Todo el contenido de esta obra, excepto donde se indique lo contrario, está bajo licencia de la licencia Creative Commons Reconocimento 4.0. 


\section{A solidariedade: \\ um inconsciente da teoria das organizações?}

Neste início do século XXI, a equação econômica não pode mais se resumir a uma oposição e/ou a uma simples complementaridade entre mercado e Estado. No plano institucional, inúmeros países têm reconhecido através de marcos legais e de políticas públicas específicas (CHAVES; DEMOUSTIER, 2015) a importância de um outro campo: a economia social e solidária. Essa emergência de um terceiro ator é fruto de numerosas tensões e de uma dupla incompletude. De um lado, os Estados perdem suas condições de assegurar seu papel regulador de estado social que lhe foi característico nos "trinta gloriosos". O enfraquecimento das regulações em matéria de política fiscal, de proteção dos trabalhadores, e de serviços públicos foi "um fator decisivo para explicar o aumento das desigualdades". (CHANCEL, 20I7, p. 67) Do outro lado, as lógicas de mercado não são capazes de garantir a sustentabilidade do seu modelo econômico. Desde então, se afirma a necessidade de novas solidariedades para refundar a ação pública.

Contudo, nossos modelos organizacionais não são adaptados para vislumbrar seriamente esta refundação. Eles sofrem em primeiro lugar de uma grande porosidade face às lógicas da economia de mercado. O vínculo forte entretido entre as ciências de gestão e a economia dominante é problemático. Pelo primado que ela atribui ao individualismo metodológico, a economia de mercado é, com efeito, incapaz de pensar a solidariedade. Além disso, a lógica de mercado é extensa e sua doutrina implicita é baseada numa lógica de expulsão, confor- 
me a seguinte ideia: "toda extensão da esfera pública reduz quantitativamente o alcance da esfera privada; toda regulação decidida pelo legislador diminui a eficácia do mercado". (FITOUSSI, 2004, p. I7) Conforme observa com ironia Rosanvallon citado por Fitoussi: "Não é mais a política, o direito e o conflito que devem governar a sociedade, é o mercado". (ROSANVALLON, I979, p. 3) Assim fazendo, as lógicas de mercado pervertem nossos modelos organizacionais e se difundem para além da esfera do mercado. O modelo organizacional da empresa é, de certa forma, "exportado" (FRANÇA FILHO, 2004) para as instituições públicas, para as organizações sociais e para as economias domésticas. Isso engendra uma constrição da esfera pública, um enfraquecimento da nossa capacidade reguladora e uma vulnerabilização tanto de lógicas institucionais quanto de organizações que servem à solidariedade.

Para inverter tais tendências, nos parece necessário realizar um trabalho profundo, de reinterrogar a história do pensamento organizacional. É preciso, muito especialmente, questionar um certo postulado permitindo a certos autores afirmar que as ciências da gestão são "inseparáveis da história das empresas". (DAVID; HATCHUEL; LAUFER, 20I2, p. 2I) Esse postulado é prejudicial pois coloca na sombra as formas cooperativas, mutualistas, associativas e a história delas. A abordagem conceitual de uma gestão solidária requer certamente um retorno sobre os fundamentos da economia e sobre os modos de produção histórica do conhecimento. As ciências da gestão são apenas ciências de suporte e apoio aos gestores formados nas lógicas de mercado? Podem elas serem críticas e adquirir legitimidade para serem ciências reflexivas sobre a gestão? (HUAULT, 2008) Podem elas se posicionar a favor da emancipação e da inversão dos mecanismos de poder e de dominação? (ENRIQUEZ, 2003; HERREROS, 20I2) Podem elas acompanhar a economia heterodoxa nas abordagens transversais afim de reconsiderar a natureza da riqueza e favorecer a produção de novos indicadores? (RENAULT, 20II; VIVERET, 2004) Após fazer um balanço sobre o nascimento e a história da gestão, nos interrogaremos sobre a possibilidade de uma contra-história. Esta, nos conduzirá a atualizar os pontos fortes de uma reflexão organizacional articulada em torno da solidariedade enquanto problemática. 


\section{SOLIDARIEDADE E HISTÓRIA DA GESTÃO: UM PERCURSO DE DESENCONTROS}

Mesmo sendo a gestão uma jovem ciência, ela já é portadora de uma história. Historiadores trabalham sobre sua análise e sua compreensão e mesmo se a história da gestão - enquanto disciplina - é muitas vezes ignorada ou negligenciada (NIKITIN, 2003), ela não tem menos importância como fonte de primeira qualidade para definir e estudar os conceitos. Ora, um aspecto notável é que a história da gestão não é unívoca. Existem várias histórias concorrentes que podem dar conta do nascimento desta disciplina. Porém, dentre todas essas histórias, há uma que domina: a história norte-americana. Doravante, o desvio pelo continente norte-americano é indispensável para compreender as lógicas atualmente em marcha sobre o pensamento gerencial.

\section{A prevalência da literatura anglo-saxônica e suas consequências}

Pesquisadores anglo-saxões (CUMMINGS; BRIDGMAN; HASSARD; ROWLINSON, 20I7) realizaram uma pesquisa muito interessante a partir das revistas mais conhecidas e mais lidas em matéria de história das ciências da organização e da gestão. ${ }^{1}$ Eles coletaram perto de 2 mil artigos publicados ao longo dos 60 últimos anos nessas revistas. Em seguida, eles codificaram esses artigos em função da localização geográfica e do seu terreno de observação. Os resultados são eloquentes. Em todos esses anos, a produção científica dessas revistas de primeiro nível se focalizou quase que essencialmente sobre os casos ingleses e norte-americanos. A Europa continental, a Ásia, a África e a América do Sul são praticamente ausentes nos trabalhos publicados. Poder-se-ia pensar que este fenômeno de dominação da língua e da cultura inglesa é geral e que não estaria dizendo nada especial sobre o campo dos conhecimentos em teorias da organização e da gestão. Entretanto, a segunda parte da pesquisa inválida essa hipótese. Com efeito, ela mostra

1 Journal of Business history, Journal of Business History Review, Journal of Management history, Journal of Management and Organization History. 
através de uma análise transversal sobre três objetos do conhecimento históricos - a medicina, a arquitetura e a gestão -, que a história da gestão é aquela que olha menos para as experiências exteriores - não anglo-saxônicas. É ela também que possui menos profundidade histórica. (CUMMINGS; BRIDGMAN; HASSARD; ROWLINSON, 20I7) Os historiadores da gestão apenas começam sua reflexão no início do século XIX. Deduz-se então que essa disciplina considera que não houve problemática organizacional nas civilizações pré-modernas, o que parece no mínimo surpreendente.

Para além da barreira da língua, se exprime evidentemente um filtro cultural cuja consequência é de invisibilizar as experiências vividas nos países não anglófonos. Isso poderia ser eventualmente admissível caso tratar-se de revistas acadêmicas com vocação nacional. Porém, levando-se em conta o papel maior desempenhado pelas revistas acadêmicas anglo-saxônicas através do jogo das classificações internacionais, um tal prisma é altamente prejudicial para o desenvolvimento do conhecimento. As consequências dessa história truncada se fazem sentir muito além da zona geográfica coberta. Reduzindo-se a história do pensamento a um fio condutor estreito tanto no plano cultural quanto geográfico, é nossa capacidade coletiva de compreender e de abordar com criatividade o futuro que é alterada. O poder performativo desse modelo de pensamento dominante não deve ser negligenciado. (CALLON, 2006)

Em termos pedagógicos, a teoria das organizações é frequentemente abordada e descrita cronologicamente nos manuais. Desde então, a narrativa da história oficial das teorias organizacionais tem um impacto potencialmente forte na formação dos quadros técnicos, gestores e daqueles que decidem, bem como, sobre suas futuras capacidades cognitivas. Ora, os manuais anglo-saxões - e muitos outros - introduzem o questionamento organizacional pela reflexão de A. Smith sobre a divisão do trabalho. Em particular, eles retêm a ideia da mão invisível que valoriza o egoísmo individual. Eles enxergam em Weber aquele que abre a via do desenvolvimento da teoria das organizações atualizando o fenômeno burocrático. Eles atribuem o nascimento da iniciativa científica da gestão à Taylor e reprovam neste último uma visão 
mecanicista da organização. Cabe então a Mayo ter clareado a importância do fator humano, perseguindo este mesmo gerenciamento científico. Por trás deste retrato cuidadoso e perfeitamente cronológico que valoriza a iniciativa individual e a empresa mercantil, parece haver muito pouco lugar para a solidariedade. De fato, a realidade é um pouco diferente. Apresentada dessa maneira, a história da gestão é reducionista com o pensamento dos autores mencionados. Ela gera um impasse sobre a complexidade da contribuição destes autores e tende a afirmar a ideia de um tempo linear na qual a teoria das organizações só teria progredido. Com Guerreiro Ramos, pode-se pensar que a teoria das organizações, tal como ela foi formada na vulgata gerencial, é antes de tudo uma expressão da ideologia de mercado. (GUERREIRO RAMOS, 198I)

Uma reflexão crítica sobre a história da gestão é mais do que nunca necessária se queremos cultivar um imaginário mais rico e desenvolver a potencialidade da disciplina. Esta redução do espectro de análise no tempo e no espaço é obviamente prejudicial para a riqueza da pesquisa acadêmica, e determina uma certa leitura da história do pensamento organizacional. Iremos agora seguir o percurso apontado nesta história oficial made in USA na busca dos encontros não realizados com as questões de solidariedade. Distinguiremos os iniciadores da disciplina, de origem europeia e, os pioneiros, essencialmente norte-americanos.

\section{A leitura truncada da obra dos iniciadores da disciplina}

Mesmo que não se possa colocar Smith na categoria dos teóricos da organização, ele é de todo modo identificado como o iniciador da reflexão sobre o campo organizacional. Reconhece-se nele o fato de ter sido o primeiro a analisar claramente a questão da divisão do trabalho e suas consequências. Ele é aquele que compreende e antecipa a demanda emergente de controle no espaço econômico e a necessidade de formar gerentes profissionais. Mas, a ideia smithiana que mais marcou os espíritos é aquela da "mão invisível". Essa metáfora muito conhecida acompanha geralmente a explicação da doutrina econômica do laissez-faire generalizado e assimila na obra de Smith a valori- 
zação dos comportamentos egoístas. Para Smith, estes seriam suscetíveis de contribuir - desde que fossem encorajados - com a riqueza de uma nação.

Nós usamos a condicional aqui porque uma leitura crítica da mesma história pode, no entanto, clarear as teorias da organização sob uma perspectiva totalmente diferente. Uma primeira constatação simples e objetiva pode ser feita sobre a obra de Smith. A expressão "mão invisível" é usada apenas três vezes em todos os seus escritos e para diferentes significados. Essa ocorrência é particularmente fraca para um conceito que deveria ser central em seu traba1ho. Na verdade, a assimilação entre "mão invisível e mercado pode [...] ser considerada como uma extrapolação que não é verdadeiramente fundamenta nos escritos de Smith". (DELLEMOTTE, 2009, p. 34) De fato, "Smith não carregava em seu coração, ao contrário de certas ideias recebidas, os grandes empresários e comerciantes". Para ele, "a ordem que emerge da livre expressão de interesses privados está, portanto, longe de estar necessariamente em conformidade com o interesse geral". (DELLEMOTTE, 2009, p. 37) Na luta que opõe os capitalistas e os trabalhadores, Smith toma explicitamente a causa dos segundos. Os primeiros são descritos "como conspiradores, apoiados pela força pública e pela lei que não hesitam em deixar passar fome a massa da população para aumentar seus lucros". (DELLEMOTTE, 2009, p. 36) Smith atribui o dever soberano de "erguer e manter certas obras públicas e certas instituições benéficas para a comunidade, mas cuja rentabilidade não é imediata o suficiente para que possam ser suportados pelo setor privado". (DELLEMOTTE, 2009, p. 37) Finalmente, Smith é a favor da tributação progressiva, conforme ele declara: "Os sujeitos num Estado devem contribuir para a sustentação do governo, cada um tanto mais quanto possível na proporção de suas faculdades, ou seja, na proporção da renda que goza sob a proteção do Estado". (SMITH, I888, p. 240)

Smith é, portanto, a favor de um imposto redistributivo. Nisso ele é muito próximo de Bourgeois (I896), um autor francês conhecido por sua defesa do solidarismo, ou seja, do fomento à solidariedade redistributista a partir do estado e outras organizações da sociedade. Se mobilizarmos uma corrente societal nas teorias das organizações, compreendemos então que "algumas 
ideias de Adam Smith sobre a importância da participação dos cidadãos na promoção do bem-estar na sociedade podem ser consideradas estando na origem dessa corrente". (DE VAUJANY; HUSSENOT; CHANLAT; 20I6, p. I5) Por que, então, os estudos gerenciais adotaram predominantemente uma visão tão redutora do trabalho de Smith, apagando tudo o que fazia parte do registro de redistribuição e solidariedade?

Weber, por sua vez, é frequentemente citado na literatura anglo-saxônica como o autor que teria aberto duas perspectivas: aquela da ampliação do questionamento das empresas em direção as organizações - numa espécie de generalização da problemática empresarial -, e aquela da consideração sobre o fenômeno burocrático. (CUMMINGS; BRIDGMAN; HASSARD; ROWLINSON, 20I7) A primeira ideia subentende um desenvolvimento cronológico do conhecimento na teoria organizacional, de Smith a Weber. Essa visão da história é criticável e problemática em si mesma porque supõe uma teleologia na produção de conhecimento. A segunda ideia é, por sua vez, redutora do trabalho de Weber. Se Weber, de fato, analisou e descreveu o fenômeno burocrático, sua análise é muito mais ampla. Ele aborda notadamente e longamente a questão da "sociação", que ele designa como uma relação fundada em um compromisso ou sob uma coordenação de interesses motivados racionalmente - por valor ou finalidade. Ele tem em conta a associação e aproveita a oportunidade para alargar o quadro da compreensão da racionalidade que pode ser expressa em valor.

Sua obra, de fato, desenha um retrato preciso de todas as racionalidades em ação na variedade de formas organizacionais, seja no mercado ou fora dele. Por que então os trabalhos sobre gestão, nesse aspecto, privilegiaram tanto, em Weber, a referência ao mercado e aos trabalhos sobre burocracia? Como Smith, Weber parece ser apreciado na ciência da administração por autores que tiveram uma leitura parcial de seus escritos. Parte da incompreensão pode ser explicada por problemas de acesso às obras e por problemas de tradução. (WEISS, I983) Na realidade, Weber nunca foi apologético sobre a burocracia. Ele está bem ciente dos seus inconvenientes. Ele observa que o fenô- 
meno burocrático é característico da evolução da sociedade moderna e deve ser analisado como tal. Contudo, centrando-se sobre o fenômeno burocrático revelado por Weber, estudos de gestão tiveram a proeza de conseguir a um só tempo: valorizar as formas organizacionais mercantis e criticar a gestão das organizações públicas. A ampliação das empresas às organizações é, na verdade, acompanhada por uma invalidação concomitante de formas organizacionais não mercantis.

Esta dupla leitura parcial (Smith, Weber) feita nos estudos de administração tem sua coerência ideológica. O foco na mão invisível de Smith legitima a lógica de mercado fundada na iniciativa privada. O foco na burocracia de Weber torna possível desqualificar os modos organizacionais não mercantis. A partir desses primórdios truncados da literatura europeia, a literatura americana da administração pôde tomar seu rumo.

\section{Os pioneiros americanos não solidários}

Partindo da divisão do trabalho revelada por Smith, Taylor desenvolve uma abordagem racional do controle e atribui à gestão seus objetivos de desempenho e eficiência. Taylor também é reconhecido por ser o primeiro a produzir uma abordagem científica para a gestão. Essa dimensão científica é a escolhida por Drucker e Maciarielo (2008) para afirmarem que a disciplina nasce com Taylor. Dessa afirmação tem origem a invalidação implícita do conhecimento organizacional anterior. Para Duncan, efetivamente, vislumbrar a existência da gestão antes de Taylor remeteria ao conto de fadas ou a uma utopia. Segundo ele, houve de fato gerentes e organizações antes de Taylor - eles citam a construção das pirâmides no antigo Egito -, mas a disciplina não poderia existir porque ninguém, antes de Taylor, teria buscado sistematizar, codificar e prescrever soluções para gerenciar que fossem melhores. ${ }^{2}$ (DUNCAN, 1989, p. 2) Aqui reside um paradoxo: nenhuma análise histórica suporta o argumento, mas a supremacia da abordagem gerencial norte-americana continua preservada. A história, definitivamente, não parece bem-vinda nos estudos de gestão. Não apenas o pensamento

2 Citado por Cummings, Bridgman, Hassard e Rowlinson, 2017. 
gerencial é capturado pelo universo anglo-saxão, mas é acima de tudo uma questão de homens e mais precisamente de homens brancos. Como salienta Laurent, nada a priori é "intrinsecamente racista na teoria econômico-filosófica clássica do livre mercado", mas não se pode ignorar que "o pensamento liberal e a exploração de povos de cor avançaram juntos". (LAURENT, 2016, p. I82) Não podemos compreender a expansão do capitalismo sem o colonialismo. Em sua amoralidade, a gestão parece ignorar a questão da escravidão, sem dúvida, para melhor reinterpretá-la. Ao naturalizar o darwinismo, o management liberal valida os sistemas de dominação postos e em particular o de dominação racial. A via para o gerenciamento científico de Taylor está aberta.

Ao afirmar que a administração nasce com Taylor, a chegada da disciplina está associada à forte ascensão da economia de mercado. De fato, a qualidade científica da abordagem de Taylor é questionável. Como mostra o trabalho de Cummings, Bridgman, Hassard e Rowlinson (2017), o próprio Taylor não tinha ambição de qualificar seu trabalho como científico. O termo lhe foi realmente atribuído por Pinchot, ${ }^{3}$ um membro do gabinete de Roosevelt, que buscava nele um apoio para promover a ideia de um gerenciamento preocupado com a conservação da natureza. Para Pinchot, a gestão científica era a que levava em conta o interesse geral. A colaboração entre ambos não se manteve, mas Taylor manteve o nome de "gestão científica", que fez sua popularidade. Se Taylor aceitasse a proposta de Pinchot, a história da gestão teria sido muito diferente. De fato, este último tinha em mente a gestão orientada para a sustentabilidade ecológica que poderia oferecer: "o maior bem, para o maior número e para o mais longo prazo". (citado por CUMMINGS; BRIDGMAN; HASSARD; ROWLINSON, 20I7, p. 324) Nisso, Pinchot era um visionário.

Se a cientificidade da abordagem de Taylor raramente é contestada, há uma crítica quase unânime do seu método. Ele é criticado por negligenciar a

3 Gifford Pinchot é o fundador do Serviço Florestal estado-unidense (US Forest Service). Foi "o homem que introduziu a profissão florestal nos Estados Unidos, depois de estudar silvicultura na Europa, especialmente em Nancy, na França. Na história das ideias, ele é o pai da 'conservação' e um dos principais pensadores da silvicultura polivalente, com as origens distantes da silvicultura multifuncional moderna (BARTHOD, 2015)". 
dimensão humana da organização e ser mantido prisioneiro de uma abordagem fria e mecanicista do trabalho. Taylor teria, então, subestimado a importância do fator humano. A partir disso, a figura de Mayo parece atraente. Ela se desenha, efetivamente, como um contraponto ao trabalho de Taylor. Mayo teria intuído a ausência da dimensão humana na análise de Taylor. A narrativa mais conhecida sugere que a descoberta de Mayo fora fruto do inesperado: em uma abordagem experimental em Hawthorne, Mayo e sua equipe teriam percebido por acaso que os ganhos de produtividade poderiam ser alcançados com maior atenção dada aos trabalhadores.

Desse modo, Mayo se inscrevia ao mesmo tempo na ruptura e na continuidade com Taylor: uma ruptura pela recusa de uma visão fria da organização; e continuidade através da busca pelo trabalho científico em gestão. Mais uma vez, essa visão histórica não suporta o teste dos fatos. Com efeito, Mayo não hesita em generalizar suas conclusões sem buscar os fundamentos. Mayo tem uma ideia fixa: ele odeia sindicatos. Prestar atenção aos trabalhadores é para ele, portanto, um mal menor, já que isso permite minar a constituição e o crescimento de sindicatos. Ao contrário do que se pôde pensar, a empresa em Hawthorne que Mayo estuda não é uma empresa como outra qualquer. Antes mesmo que Mayo venha pesquisá-la, ela era conhecida por ter desenvolvido uma política de apoio e ajuda aos seus trabalhadores. Na verdade, ela é pioneira em matéria de política de recursos humanos. É interessante notar que essa empresa acolhe comunidades de trabalhadores estrangeiros. Ao cuidar financeiramente de cada uma dessas comunidades, a empresa consegue impedir o estabelecimento de sindicatos. Assim, Mayo não estuda uma empresa em que assalariados não recebem atenção, mas, pelo contrário, uma empresa muito atenta ao destino de seus trabalhadores. Portanto, o escopo do trabalho apresentado por Mayo é bastante reduzido. Samson e Daft (20I2) são categóricos em suas análises. Eles quebram a cientificidade do trabalho de Mayo. Segundo eles, o dinheiro é a melhor hipótese para explicar o aumento da produtividade observado por Mayo. O caso está encerrado, mas isso não impede que as ideias falsas continuem seguindo seu caminho. 
Assim, a oposição que acabamos de apontar entre Taylor e Mayo se refere em parte àquela de Smith e Weber. Taylor busca racionalizar a cadeia de trabalho e se recusa a qualquer estado de espírito. Nisso ele se pretende amoral. Ele afirma ser capaz de responder aos desafios enfrentados pelas empresas de seu tempo através de uma nova organização do trabalho. Os trabalhadores devem aceitar as consequências. Os sacrifícios de hoje são os lucros de amanhã. A proposta taylorista encontra, assim, sua extensão natural e seu momento de glória no fordismo. Postulando a possibilidade de uma reversão do mal em bem, Taylor retoma a figura de linguagem da mão invisível que entende transformar o egoísmo em virtude. Contudo, Taylor não considera outras solidariedades além daquelas que se expressam friamente na cadeia do trabalho. Mayo é diferente de Taylor em termos de método. Seu trabalho pretende enfatizar a necessidade de atenção imediata aos trabalhadores e fornece os primeiros argumentos que favorecerão o surgimento de uma teoria de recursos humanos. Eles se juntam, no entanto, em uma perspectiva amoral. Segundo Mayo, não se trata para os patrões das empresas de participar da emancipação dos trabalhadores, mas acima de tudo de evitar riscos de confronto que perturbariam a produção de bens e serviços. Mayo, portanto, se junta à Taylor em uma certa forma de cinismo e na rejeição de uma solidariedade forte entre as classes sociais. É verdade que ambos os autores enxergam a empresa como um sistema fechado e autossuficiente. Eles parecem não ver que a gestão é portadora de uma questão que ultrapassa as fronteiras estreitas da empresa e que é potencialmente revolucionária.

\section{Pode a revolução gerencial ser solidária?}

Quando Burnham publica um livro intitulado A Revolução Gerencial em I94I, ele imediatamente vinculou a administração à política econômica nacional e internacional. No período que surge a Guerra Fria entre os dois blocos Leste-Oeste, Burnham aposta na gestão para aliviar as tensões e reduzir o risco de conflito. Ele considera a gestão como uma fonte de superação das deficiências de cada um dos sistemas: economia dirigida e economia capita- 
lista. Ele adianta a ideia de que "aparentemente não há razão para pensar que a economia gerencial estará sujeita às crises experimentadas pelo capitalismo, uma vez que os fatores envolvidos nesse tipo de crise - que estão relacionados à restrição do lucro - serão rejeitados por este". (p. I25) Ele vê a gestão como uma forma de evitar crises. Para ele, o advento da revolução gerencial é uma garantia de fusão entre o Estado e a economia e de superação dos sistemas formados no início do século XX. Portanto, a revolução gerencial sugere uma outra forma de solução de problemas suscetível de apreender na mesma abordagem as dimensões técnica, econômica e política. A intuição não está errada, mas a história infelizmente não dará razão a Burnham. A revolução gerencial está ocorrendo, mas infelizmente não é a promessa esperada de uma pacificação do mundo.

Burnham observa que o crescimento do tamanho das empresas favoreceu o desenvolvimento da gestão. Ao mesmo tempo, os métodos burocráticos também se desenvolveram fortemente nas administrações governamentais e na arena política. Para Burnham, trata-se do mesmo fenômeno. Burocracia e gestão participam do mesmo pensamento organizacional. Sua convergência anuncia a fusão do campo econômico e político. Como esse fenômeno é observável em ambos os lados do Muro de Berlim, Burnham o vê como uma dimensão revolucionária. Ele afirma:

Se os problemas políticos são resolvidos por métodos racionais, nós devemos, muito provavelmente, esperar que o sistema político de uma sociedade gerencial assuma a forma de um único Estado-mundo. Dessa maneira, a anarquia que necessariamente segue os conflitos de soberania seria totalmente eliminada. A produção mundial poderia ser organizada da maneira mais eficiente, fazendo o melhor uso dos recursos globais e tomando as decisões mais eficazes. A duplicação desnecessária poderia ser evitada, e a terra, o clima, as pessoas e os recursos poderiam ser explorados da maneira mais lucrativa. (BURNHAM, I94I, p. I65) 
Essa feliz mudança para Burnham ocorre na época da Segunda Guerra Mundial. Para ele, de fato, "a guerra de I9I4 foi a última grande guerra da sociedade capitalista e a guerra de I939, a primeira grande guerra da sociedade gerencial". (BURNHAM, I94I, p. I68)

O livro de Burnham é um sucesso nos Estados Unidos. Dizem que ele inspirou Orwell em seu romance 1984. Esse sucesso esconde, contudo, um importante elemento biográfico da vida de seu autor: até i940, Burnham era comunista, mais precisamente, ele era um trotskista. Ele via ingenuamente na ascensão dos organizadores uma capacidade de regulação emergente entre a burguesia e o proletariado. Ao abandonar a revolução comunista pela revolução gerencial, Burnham cometeu o erro de todos os novos convertidos. Ele empresta um pouco demais de virtudes para a revolução a que ele se junta. Ao colocar o realismo no centro da reflexão, a revolução gerencial não pacifica o mundo nem o solidariza. Ela só the dá uma forma suave não favorecendo possibilidades de críticas. No entanto, o trabalho de Burnham marca os espíritos e traz duas ideias poderosas para entender o mundo moderno: a gestão se generalizou, e se tornou um vetor de regulação. Nesse sentido, ele tem uma dimensão institucional.

\section{A empresa como instituição}

Em comparação com os autores pioneiros, a teoria neoinstitucional mexe nas bases. Abandona o postulado da racionalidade instrumental perfeita. A economia institucional de Coase e Williamson vê a empresa como um sistema aberto. (COASE, I937; WILLIAMSON, 1985) A empresa é pensada como uma instituição em sua relação com outras instituições como o mercado. A informação é central neste quadro conceptual. Se o acesso às informações no mercado é fácil e os fornecedores são numerosos, é rentável subcontratar suas atividades. Caso contrário, os custos de transação podem ser altos e favorecer a escolha de um controle hierárquico interno da atividade dentro de uma empresa. Assim, a economia institucional justifica pelo mercado a necessidade de criar instituições fora do mercado. Esse esquema de pensamento legitima a existência 
de empresas organizadas na forma de hierarquia. Quanto ao indivíduo, ele arbitra entre "a busca do lucro como trabalhador autônomo e o salário como empregado de um sistema hierárquico". (DOUGLAS, 2004, p. 8I) Ao separar assim a empresa do mercado, tornando-as duas instituições, os autores neoinstitucionalistas reconhecem, como Simon (1955), que "a racionalidade humana tem seus limites" e que "doravante é comum considerar a organização institucional como forma de compensar os limites da racionalidade". (DOUGLAS, 2004, p. 82) Elas também reconhecem que existem arranjos institucionais que podem ser mais pertinentes do que o mercado. De fato, em seu artigo "The nature of the firm", Coase (1937) procura entender por que as empresas existem. Ele propõe uma reflexão que articula a lógica do mercado e a lógica hierárquica interna às empresas. É a instituição que gerencia e armazena as informações. Assim, ela reduz a incerteza.

Poderíamos continuar a história do pensamento dizendo que, ao mostrar a importância da firma entre mercado e hierarquia em uma visão neoinstitucional, Williamson e Coase finalizaram a reflexão em matéria de organização. Eles fizeram a conexão entre Smith e Weber. Para Bonnafous-Boucher (2005), a abordagem institucional de Coase e Williamson participa de um avanço na medida em que permite considerar a empresa como um sistema "sem enraizamento em um modelo cientificista, seja biológico ou cibernétiCo". (BONNAFOUS-BOUCHER, 2005, p. IO8) No entanto, é preciso se entender sobre a definição dada ao conceito de instituição. Como Douglas assinala, "o interesse demonstrado pelos economistas nas estruturas institucionais não diz praticamente nada sobre a temática da legitimação, embora a questão da autoridade seja às vezes mencionada". (DOUGLAS, 2004, p. 80) Mary Douglas entende por instituição um agrupamento social legitimado. Para os antropólogos, não é apenas uma questão de saber se uma organização é uma instituição, mas também "sob quais condições ela a é". (BONNAFOUS-BOUCHER, 2005, p. I08) É a razão pela qual a antropologia enfatiza o "simbolismo social e cultural que nada mais é do que a análise das instituições" (BONNAFOUS-BOUCHER, 2005, p. IO8) e que é frequentemente negligenciado pela teoria 
das organizações. Essa abertura no campo econômico da questão institucional, no entanto, inaugura uma reflexão mais ampla sobre a empresa como instituição social. Ela permite a possibilidade de uma primeira consideração da solidariedade no contexto de uma empresa que, de agora em diante, é qualificada como "social".

\section{A firma como uma empresa social à vocação societal}

O debate internacional sobre empresas sociais é amplamente dominado pela literatura norte-americana. A primeira definição do conceito avançou nos EUA na década de 1990 por pesquisadores da Harvard Business School. Para eles, uma empresa social é capaz de se doar e perseguir um duplo objetivo: econômico e social. Esses tipos de empresas existem, segundo essa perspectiva, porque elas são dirigidas por empreendedores sociais altruístas. Esses últimos são motivados pelo desejo de articular um projeto de empresa remunerador com a defesa de uma causa social.

$\mathrm{Na}$ linha desse movimento de pensamento, Yunus (2008b) propôs o conceito de negócio social para projetar empresas que seriam suscetíveis de redefinir a face do capitalismo. A ideia que ele defende é de favorecer a evolução para um novo capitalismo, em que as empresas teriam um duplo objetivo: o lucro e uma causa social. Para Yunus, as empresas podem estabelecer objetivos sociais e alcançá-los se se apoiarem em grupos que estão cientes de suas responsabilidades sociais. A ideia pode parecer atraente para os Estados endividados que enfrentam crescentes necessidades sociais. Respondendo às aporias da economia de mercado, acredita-se então que esse empreendedorismo social poderia enfrentar o problema da pobreza.

Os entusiastas dos negócios sociais estão convencidos de que esse novo capitalismo pode funcionar "de acordo com os princípios de gestão que prevalecem em uma empresa clássica" (YUNUS, 2008a, p. 52-53) e oferecer a garantia de cobrir de uma só vez os seus próprios custos e aqueles do social. Portanto, não é necessário alterar os métodos de gerenciamento ou adotar uma racionalidade diferente. Basta adaptar-se às restrições impostas e encontrar as soluções 
mais eficazes dentro da estrutura escolhida. O negócio social se junta, assim, à ideia de Big Society ${ }^{4}$ apresentada por David Cameron em 20IO. O empreendedorismo social, a filantropia de risco e o paternalismo libertário se entrelaçam para formar uma sociedade neoliberal ideal. (CORBETT; WALKER, 2OI3) Vemos aqui o quanto o capitalismo - embora se defenda - compartilhe com as outras doutrinas uma dimensão inegavelmente utópica. (ROSANVALLON, 1979)

Se, dentre os autores que acabamos de mencionar, Yunus oferece, com seu conceito de negócio social, a versão mais acabada de um empreendedorismo humanista, não podemos dizer que o objetivo é realmente solidário. O negócio social aparece principalmente como uma ilustração de uma tentativa de moralizar o capitalismo. (THOMPSON, I988) Nesse sentido, não pode ser tomado como referência para quem busca repensar a gestão sobre o princípio da solidariedade. Embora esse tipo de empresa exprima frequentemente a necessidade de lutar contra a pobreza, é raro que os seus empresários procurem defender um modo de governança alternativo e corrigir as desigualdades na raiz. O discurso virtuoso do social se parece com uma retórica da vacina "que consiste em confessar o mal acidental de uma sociedade de classes para melhor disfarçar o mal principal. Imuniza-se o imaginário coletivo por meio de uma pequena inoculação do mal reconhecido; e defende-se assim contra o risco de uma subversão generalizada". (BARTHES, I970, p. 238) A empresa social - em sua definição anglo-saxônica - permanece, portanto, uma empresa de mercado com gestão e governança clássicas. Ela não parece em condições de atender então às expectativas da revolução gerencial de Burnham.

\section{O esquecimento da solidariedade e suas consequências}

Para concluir esta parte, podemos traçar um paralelo entre a oposição de Smith e Weber, por um lado, e a de Taylor e Mayo, por outra parte. Enquanto Smith procura produzir uma teoria que permite "des-moralizar" a política econômica, fazendo emergir as "leis naturais" do mercado, Weber tem por

4 Big society pode ser traduzida como "grande empresa" e foi um slogan político usado durante a campanha eleitoral em 2010 pelo Partido Conservador britânico. 
ambição nutrir uma visão mais ampla. Para ele, o mercado não é mais do que uma das formas de racionalidade no trabalho. Taylor, por sua vez, faz parte da filiação de Smith e procura traduzir as leis do mercado em um método de gestão. Como as leis naturais, sua visão da organização é amoral e pretende sair de um consenso paternalista. Esse não é o caso de Mayo. Na sua ambição de reduzir o conflito interno das empresas exacerbadas pela visão taylorista, Mayo propõe, pelo contrário, uma moralização da gestão. Ele se junta à possibilidade de um consenso popular sobre uma forma de economia moral descrita por Thompson, como justificativa do paternalismo e como instauração de uma economia moral dos pobres.

Burnham, por seu lado, é um dos primeiros escritores da administração a procurar estabelecer uma conexão entre a visão de Smith e aquela de Weber. Para Burnham, a gestão anunciada por Smith e a burocracia de Weber fazem parte do mesmo movimento para pacificar o mundo. A racionalidade que se exprime nos dois espaços implementa procedimentos que permitem religar a política à economia. A abordagem de Burnham é semelhante à da Escola Econômica Institucional, na qual Coase e Williamson também procuram conectar o trabalho de Smith e Weber. Mas estes enxergam o mercado e a empresa hierárquica como duas instituições que precisam ser articuladas. Se a visão de Burnham é ingênua, a de Coase e Williamson é puramente técnica. A questão da articulação entre as duas instituições é resolvida pela estimativa dos custos de transação. Portanto, a ligação que é feita entre a abordagem de Taylor e Mayo não nos permite sair de uma visão fria ou paternalista das relações sociais dentro da organização hierárquica. A tentativa de superar essa questão pela empresa social - que mostra uma preocupação com a integração da questão social - permanece, no entanto, refreada pelo não questionamento da gestão clássica.

Vimos que a história da administração poderia ter sido muito diferente a partir dos mesmos indícios se os autores pioneiros tivessem feito outras escolhas de análise. Tanto o trabalho de Smith quanto o de Weber se prestaram a uma visão ampla das problemáticas organizacionais nas quais a questão da 
solidariedade estava presente. Se Taylor tivesse seguido as propostas de Pinchot, a administração científica poderia ter se colocado a serviço da sustentabilidade ambiental. Se Mayo realmente quisesse explorar a questão da atenção aos trabalhadores da empresa, ele teria explorado a emergência das formas de organização cooperativa das quais ele era contemporâneo. A leitura parcial de Smith e Weber e a visão parcial dos autores pioneiros engajaram a administração num caminho em que a questão da solidariedade dos homens com a natureza e dos homens entre eles mesmos é evitada. Essa preocupação em evitar qualquer referência a um valor mais alto, como a preservação da natureza ou o respeito pelas pessoas, teve duas consequências importantes: o desaparecimento do sujeito e a fuga em direção a uma cultura de mudança perpétua.

Como Boltanski (2015) mostra, "uma das propriedades mais relevantes da dominação gerencial é [...] de estar sem sujeito". (BOLTANSKI, 20I5, p. 2OI202) A ausência de um sujeito é determinante na medida em que impede a resistência dos atores envolvidos na ação coletiva. Nessa lógica, entende-se sempre que é "a necessidade, no sentido de uma necessidade causal, que dita as medidas tomadas, fornecendo para tanto uma explicação, mais do que uma justificativa". (BOLTANSKI, 2015, p. 202) Não há, portanto, necessidade de exercer a ameaça ou de viver em um clima de terror para manter a dominação. É suficiente exigir que todos os atores sejam realistas e aceitem as restrições econômicas que lhes são apresentadas "não porque elas são boas ou justas em si mesmas, mas porque elas não podem ser outras que elas não são". (BOLTANSKI, 2015, p. 204) Este é o sistema TINA "there is no alternative" caro a Thatcher. Compreende-se, portanto, como a revolução gerencial anunciada por Burnham teria podido alimentar um amplo sentimento de impotência cuja consequência é "o afastamento das esferas da ação política e, acima de tudo, a falta de interesse, não apenas pelo militantismo, mas mesmo por essa forma mínima de atividade política que consiste em ir votar". (BOLTANSKI, 2015, p. 204)

Um segundo ponto de importância para compreender a força do regime de gestão reside na sua apologia à mudança. Privados de referência externa, 
os gerentes nunca deixam de valorizar a mudança e de teorizar sua implementação. Uma das principais tarefas do gerente de equipe é reduzir a resistência à mudança. Isso faz com que Boltanski disesse: "Essa reconciliação, estranha quando você pensa sobre ela, da vontade - isto é, da liberdade - e da necessidade, que tem sido freqüentemente associada a regimes totalitários reivindicando uma filosofia determinista da história, ainda constitui um lugar comum dos modos de governança do capitalismo avançado". (BOLTANSKI, 2015, p. 207) O desejo de mudança permanente está na origem de uma contínua recomposição do real que mantém e alimenta o que Bauman (2000) chama de "sociedade líquida", isto é, uma sociedade em que reinam o consumo e o descartável. Para manter essa corrida, a sociedade gerencial se funda "sobre uma forma de autoridade - a dos especialistas - que entende se situar no ponto de indiferenciação entre a realidade e o mundo". (BOLTANSKI, 20I5, p. 210) Em um ambiente caracterizado pela incerteza, os especialistas compõem e recompõem as grades de leitura do mundo. Então, eles estão sempre um passo a frente dos seus adversários. As críticas aos especialistas só podem ser, por sua vez, de especialistas. A legitimidade das palavras é, assim, retirada do cidadão comum não especialista. A crítica se encontra encurralada na lógica da dominação e nas "querelas entre expertise e contra-expertise, nas quais a contra-expertise é necessariamente dominada e, na maioria das vezes, perdida, uma vez que não pode alcançar a expertise, isto é, tornar-se elegível ou simplesmente audível, apenas se duplicando aos formatos de provas postos em prática por este último". (BOLTANSKI, 2015, p. 212) Assim, a deriva da gestão descrita por Boltanski bloqueia qualquer consideração sobre a solidariedade. Para sair deste sistema de dominação, o recurso à uma contra-história se faz necessário.

\section{DA HISTÓRIA À CONTRA-HISTÓRIA}

Depois de mostrarmos como a história da administração se construiu por fora da questão da solidariedade, em razão justamente dos inúmeros "encontros não acontecidos", iremos neste momento enfatizar os autores solidários 
esquecidos. Embora negligenciados, esses autores são numerosos e formam uma rica trama de pensamento para desconstruir a versão oficial da administração e considerar uma reflexão crítica propícia a favorecer o surgimento de uma escola de pensamento organizacional solidário. Em primeiro lugar, deve-se notar que, embora os grandes autores da gestão sempre tenham se recusado a colocar a solidariedade no centro de suas análises, eles não conseguiram expulsá-la. Ela permanece no fundo do inconsciente do gerente como um pensamento reprimido. De Taylor a Mayo, de Williamson a Yunus, a questão da solidariedade pesa. Não pesa na consciência desses autores, mas pesa sobre a realidade de um mundo vivo que eles tentam disciplinar. Como conciliar a liberdade que é seu princípio orientador com a rigidez provocada pelo fator humano e pela natureza? A partir dessa confrontação nascem problemas sem fim que não se pode iludir por muito tempo. O próprio Marx havia pontuado o problema ao mostrar que o capitalismo esgota ao mesmo tempo "as duas fontes de onde brota toda a riqueza: a terra e o trabalhador". (MARX, I948 apud COUTROT, 20I8, p. 65)

A evolução do pensamento gerencial mostra o retorno do reprimido. Burnham viu na gestão uma possível ligação entre o mercado e o comunismo. Em uma versão mais polida, Williamson e Coase reconhecem a dimensão institucional da economia e fazem uma conexão entre o mercado e a organização. Ao fazer isso, eles tiram a gestão da utopia onipresente do mercado e tentam se aproximar do mundo vivo. No entanto, sua abordagem é formal. Eles apenas reconhecem a empresa como instituição para melhor convertê-la ao mercado. Os custos de transação serão, assim, colocados a serviço da externalização das atividades das empresas e o desenvolvimento da subcontratação. Esse fenômeno de amplitude mundial induzirá a fragilização de todos os sistemas de solidariedade coletiva nacionais. A irrupção do conceito de empresa social é uma resposta tardia e tímida a essa fragilização. Mais uma vez, a resposta é insuficiente. Se a empresa social reconhece a presença de um mundo vivo e a necessidade de levá-lo em consideração num contexto econômico, ela não deduz a ideia de uma transformação da gestão. A empresa social de Yunus serve a luta contra a pobreza com os métodos clássicos de adminis- 
tração herdados de Taylor e Mayo. A empresa social - versão social business aparece, então, mais como uma extensão do mercado em direção ao social - e uma mercantilização dele -, do que uma consideração real do social para fins da reforma do mercado. Podemos deduzir a partir desse conceito que as ideias liberais progridem hoje, se apreendendo do social. (CHAUVIÈRE, 2007) Para escapar da aporia desse pensamento, devemos, portanto, levar em consideração outros autores. Esse é precisamente o objeto da sequência deste capítulo.

\section{A compatibilidade entre solidariedade e organização}

A hipótese de uma revolução gerencial em Burnham é interessante porque está na encruzilhada de uma lógica de mercado e de uma lógica de Estado. Ela é teoricamente fraca porque não constrói nada preciso nessa junção. Compreendemos, portanto, que os autores que serão capazes de nos ajudar na definição de uma gestão solidária serão aqueles que levantarão a hipótese de uma outra economia, isto é, uma economia que não se resume nem ao mercado e nem a uma economia planificada controlada pelo Estado. Trata-se, portanto, de ver que "o mercado e o Estado não são mais capazes, por si mesmos, de proporcionar emprego, atividade, dignidade e auto-estima a todos. Daí a necessidade de fazer emergir, ao lado e em interação com eles, um terceiro pilar, ao mesmo tempo econômico, ético e político, a própria sociedade, cuja ponta de lança seria formada pelas associações". (CAILLÉ; LAVILLE, I998, p. 6)

O primeiro autor que nos ajuda a colocar a organização solidária é Leroux. Esse autor aborda "o difícil problema do laço social, começando por traçar um triângulo em que estado, mercado e associação, ou seja, a própria sociedade, são as três pontas". (VIARD: VAILLANCOURT, 2000, p. 26) Leroux vê na solidariedade uma "metafísica renovada" (LEROUX, I860, p. 62) que nos permite ir além da visão dicotômica da sociedade - por uma parte abandonada ao egoísmo e por outra entregue à caridade. Como observado por Viard, Leroux tem uma visão binocular que tenta reconciliar o individualismo metodológico e o holismo. (VIARD; VAILLANCOURT, 200o) Para Leroux, "o individualismo absoluto consiste em tomar sem dar, enquanto o socialismo 
absoluto consiste em dar sem receber. Isso resultou nas duas utopias complementares, liberal e estatal". (VIARD; VAILLANCOURT, 2000, p. 24) No alvorecer da sociedade moderna, Leroux coloca: "os princípios antropológicos e políticos suscetíveis de inspirar uma regeneração do atual laço social sobre uma base solidária e associativa". (VIARD; VAILLANCOURT, 2000, p. 8) Leroux inscreve-se na rica filiação de outros autores importantes:

Em Saint-Simon, o mestre, Leroux reconhece o mérito de ter previsto a nova Era invertendo a fórmula rousseauniana e de ter proposto uma nova organização da humanidade fundada sobre a indústria. A descoberta de Saint-Simon é a associação. [...] Em Fourier, Leroux saúda aquele que lançou a especulação utópica mais longe [...] Quanto a Owen, ele anunciou o reinado das máquinas e o fim da servidão social. (ABENSOUR, 2013, p. I23)

Já em dezembro de I790, Robespierre havia inscrito os três termos "Liberdade, Igualdade, Fraternidade" na bandeira tricolor da Guarda Nacional, mas foi apenas na revolução de I848 que esse lema se torna oficialmente aquele da República. (VIARD; VAILLANCOURT, 200o) Retomando os três princípios do lema republicano francês "Liberdade, Igualdade, Fraternidade", Leroux observa que o terceiro termo é frequentemente negligenciado. Ele salienta que a liberdade está associada ao mercado e à igualdade ao Estado. Mas, e a que está associada a fraternidade? Muitas vezes ridicularizada, inclusive por Marx (VIARD; VAILLANCOURT, 2000, p. 20), Leroux pretende reabilitá-la. Assim, ele pretende "reconciliar a liberdade e a igualdade colocando a fraternidade entre elas". (VIARD; VAILLANCOURT, 2000, p. 20) Ele escreveu em I842 em seu discurso aos políticos: "Eu coloco a fraternidade no centro da fórmula porque ela é o elo entre a liberdade de cada um e a liberdade de todos". (citado por VIARD; VAILLANCOURT, 2000, p. 24)

Segundo Leroux, é necessário que "o homem finalmente renuncie a um longo erro, que o fez buscar fora do mundo, fora da natureza, da vida, um paraíso imaginário". (LEROUX, I840) Para Leroux, o retorno ao mundo vivo passa pelo conceito de solidariedade. Ele permite pôr de lado a caridade cristã, 
que é da ordem da piedade e da comiseração, e o mercado que é da ordem do individualismo e do egoísmo. Ao fazê-lo, Leroux permite uma renovação de pensamento. De fato, ao contrário da caridade e do egoísmo, a solidariedade pertence inteiramente ao reino do organizável. Leroux afirma que "só a solidariedade é organizável". (LEROUX, I840) Para um gestor, a ideia é interessante e vai inspirar outros autores.

\section{A solidariedade baseia-se num quase contrato}

Léon Bourgeois é, sem dúvida, o autor que mais influenciou o pensamento solidário. Seu livro Solidariedade foi muito lido na França e este autor beneficiou em sua vida de uma aura importante. (BOURGEOIS, I896) O pensamento de Bourgeois, no entanto, continua a ter uma forte atualidade, na medida em que sua reflexão se baseia na observação de que o bem-estar dos homens não aumentou com o imenso progresso da ciência e da tecnologia. Apesar da riqueza acumulada, as desigualdades persistem e crescem. Bourgeois considera que uma necessidade moral é imperativa para corrigirmos esse estado de coisas. Mas a força do seu propósito é deixar de lado a questão moral para se concentrar no que ele chama de lei universal: a solidariedade. Ele afirma que "os homens são colocados entre si e mantidos em laços de dependência recíproca, como são os seres e todos os corpos, sobre todos os pontos do espaço e do tempo". (BOURGEOIS, 2OI5, p. 50) Portanto, os homens devem se organizar para reconhecer os laços de solidariedade que os conectam no tempo e no espaço.

Essa organização tem uma aparência contábil. Bourgeois fala de dívida. O homem nascendo e crescendo é devedor de seus contemporâneos. Assim, "desde o dia do seu nascimento, ele é um obrigado. O homem nasce devedor da associação humana. Ao entrar na associação, ele recebe sua parte de uma herança acumulada". (BOURGEOIS, 2OI5, p. II6) Portanto, "é para todos que virão depois de nós que nós temos recebido dos antepassados a carga de quitar a dívida que recebemos". (BOURGEOIS, 20I5, p. I24) A solidariedade é trans- 
geracional. Para Bourgeois, "é um legado de todo o passado para todo o futuro". (BOURGEOIS, 20I5, p. I24) Reconhecer a dívida dos outros em relação às outras gerações é reconhecer a natureza coletiva de nossa organização social. O homem não pode "se subtrair materialmente ou moralmente da associação humana. O homem isolado não existe". (BOURGEOIS, 20I5, p. 137)

A força da proposta de Bourgeois é que ela pode ser operacionalizada. A dívida da qual ele fala não se traduz em um questionamento dos direitos atuais, mas em sua moderação por um princípio universal. Assim, para ele, "reconhecer uma dívida não é abandonar um direito, é reconhecer o verdadeiro limite desse direito". (BOURGEOIS, 20I5, p. IO3) Para tanto, ele forja o conceito de "quase-contrato". Esse quase-contrato liga todos os homens sem que tenham consciência. O avanço intelectual que Bourgeois propõe está precisamente na conscientização e operacionalização desse quase-contrato. O objetivo deste último é traduzir na organização coletiva "a avaliação eqüitativa dos serviços trocados, isto é, a distribuição eqüitativa de lucros e despesas, do ativo e do passivo social que é o objeto legítimo da lei social". (BOURGEOIS, 2015, p. 138) Porque a dívida é intergeracional, há "para todo homem vivo uma dívida para as gerações futuras em razão dos serviços prestados pelas gerações passadas". (BOURGEOIS, 20I5, p. I38)

Na sua proposição de um quase-contrato entre os homens, Bourgeois utiliza um conceito de gestão para estabelecer uma ligação entre critérios econômicos e não econômicos. Assim, Bourgeois reconhece que "o homem não tem apenas interesses econômicos, ele tem interesses fisiológicos, psicológicos e morais". (BOURGEOIS, 20I5, p. I44) Por meio de sua proposta de reconhecimento da dívida, ele entende que "a definição dos direitos e deveres dos homens não pode mais ser buscada fora das relações que os ligam solidariamente no espaço e no tempo". (BOURGEOIS, 20I5, p. 80) A noção de quase-contrato nada mais é do que a própria dádiva (CHANIAL, 20IO), ou seja, a necessidade de ter um vínculo. (CAILLÉ, 1994) O quase-contrato pode também ser visto como uma outra concepção do contrato social. (LAVILLE; ROUSTANG, I996) 


\section{A solidariedade e "o interesse bem-compreendido"}

Se Tocqueville é um liberal que "exclui da igualização das condições toda igualdade econômica" (MENGER, I923, p. 2Io), por outro lado, ele não subscreve a noção da mão invisível atribuída a Smith. Segundo ele, a adição dos egoísmos não pode estar na origem da riqueza das nações. Para ele, isso não faz sentido. Reconhecendo, entretanto, o problema levantado por Smith, ele propõe o conceito de "interesse bem compreendido" como uma forma de resolução de tensões entre os indivíduos e o coletivo. Esse conceito consiste em oferecer a cada cidadão de uma democracia a perspectiva de trabalhar pela felicidade de todos enquanto defendem sua própria vantagem individual. Tocqueville, assim, avança "uma teoria do interesse nas democracias, onde a adição de interesses particulares torna possível identificar mais ou menos o esqueleto do interesse geral". (MENGER, 2002, p. 208) Tocqueville procura entender como o equilíbrio democrático pode garantir a coincidência necessária entre os interesses dos que estão no poder e aqueles da população. Para isso, Tocqueville precisa inclinar-se para o que promove o interesse dos indivíduos pelos assuntos públicos. Ao observar a vida associativa, ele vê nela um meio para que o engajamento cidadão seja assegurado. (CHANIAL, 20IO; CEFAÏ; CHANIAL, 200o) Tocqueville é o primeiro autor a apontar as associações como os principais vetores de solidariedade no espaço social e econômico. Nisso, ele é um autor inovador. Ele considera que a associação deve receber toda atenção e afirma que "nos países democráticos, a ciência da associação é a ciência mãe; o progresso de todas as outros depende do progresso dela". (TOCQUEVILLE, I848, p. 22I)

Isso equivale a colocar a questão da solidariedade no centro de sua análise. Se sua proposta é pertinente, a voz de Tocqueville infelizmente tem pouco peso em comparação com a de Smith. À Tocqueville é negada qualquer competência como economista e isso desacredita e invalida sua resposta a Smith. Ao ressaltar a importância da participação de todos, Tocqueville, no entanto, enfatiza um ponto crucial. Ele entendeu o perigo inerente às democracias quando a ausência ou falta de compromisso cívico e associativo faz o leito 
das ditaduras. Embora preocupado com o desenvolvimento econômico, ele é particularmente clarividente sobre a dimensão civilizatória da solidariedade. Ele nota assim que se quisermos que "os homens permaneçam civilizados ou se tornem, é necessário que entre eles a arte de se associar seja desenvolvida e aperfeiçoada na mesma relação que a igualdade das condições aumenta". (TOCQUEVILLE, I848, p. 22I) Ficamos, assim, diante de uma questão de extrema atualidade.

\section{A solidariedade no centro do pensamento organizacional}

Ferdinand Tönnies nos ajuda a pensar sobre a natureza do vínculo solidário. Ele distingue os laços pessoais duradouros que nascem nos espaços sociais primários - família, vizinhança, amigos etc. - e os elos impessoais mais efêmeros que são constituídos no espaço mais amplo da sociedade moderna. Para Tönnies, os primeiros se alimentam da proximidade afetiva e espacial dos indivíduos e determinam "uma comunidade de lugar, sangue, espírito". (TÖNNIES, 20Io) A sociedade, por outro lado, é o espaço de um individualismo frenético, de uma competição generalizada entre os homens, o reino do interesse próprio. O homem da sociedade escolhe arbitrariamente suas relações em função do interesse pecuniário que ele pode esperar. A dissolução dos laços comunitários, que são vetores de fortes formas de ajuda mútua em benefício de novas formas de socialização, é um fator de empobrecimento do vínculo social. Tönnies critica Smith para quem a sociedade é o estado em que "todo homem é um comerciante". Essa visão economicista da sociedade é precisamente o que ameaça, segundo Tönnies, o laço social genuíno e desinteressado.

Durkheim tenta ir além da visão de Tönnies, que ele diz ser testemunha de uma nostalgia em uma era de ouro passada. Mais precisamente, o ideal de Tonnies, segundo Polanyi (20II), era

a restauração da comunidade - não por um retorno à era pré-industrial da sociedade, mas pela promoção de uma forma mais elevada de comunidade que sucederia nossa civilização 
atual. Seria, aos seus olhos, uma espécie de fase de cooperação da civilização, que reteria os benefícios do progresso tecnológico, bem como a liberdade individual, enquanto restaurava a integridade da vida. Até certo ponto, sua posição lembrava a de Robert Owen ${ }^{5}$ ou, entre os pensadores modernos, a de Lewis Mumford. ${ }^{6}$ (POLANYI, 2OII, p. 94)

Durkheim, por sua vez, critica essa visão que ele considera partidária: "Podemos ver que, em suma, a sociedade que Tönnies está atualmente retratando é a sociedade capitalística dos socialistas; e, de fato, o autor muitas vezes toma emprestado de Karl Marx e Lassalle as cores escuras sob as quais ele nos representa". (DURKHEIM, I975) Para Durkheim, as sociedades modernas são tão naturais quanto as sociedades tradicionais menos extensas. Ele, portanto, se recusa a favorecer uma sobre a outra.

Onde Smith vê uma lei natural que leva os homens a dividir o trabalho à medida que a produção aumenta, Durkheim se questiona sobre um paradoxo: como uma sociedade pode se adaptar ao desenvolvimento do individualismo em seu seio sem questionar os princípios sobre os quais ela se funda? Durkheim resolve a aparente contradição analisando a transformação da solidariedade. Para isso, ele distingue em sua demonstração dois tipos de solidariedade. O primeiro, que ele qualifica de solidariedade mecânica, funciona por similaridade. Ele se refere às sociedades tradicionais, onde os indivíduos são pouco diferenciados uns dos outros em termos de atividade e onde há uma grande homogeneidade entre os membros que constituem a sociedade. A segunda, descrita como solidariedade orgânica, caracteriza as sociedades modernas. Ela dá a cada um uma posição social precisa e uma diferenciação nas tarefas a serem realizadas. Essa solidariedade oferece um controle social menos estreito pois ela autonomiza seus membros.

5 Robert Owen é um pensador inglês nascido em 1771, conhecido por ter desenvolvido uma visão de um novo mundo moral ancorado no movimento cooperativista.

6 Lewis Mumford (1895-1990) é um historiador estadounidense das técnicas que desenvolveu uma visão crítica da sociedade industrial. 
Durkheim mostra que as sociedades tradicionais têm uma forte consciência coletiva. Isso tem como consequência manter a coesão do grupo pela absorção e homogeneização dos indivíduos. Nas sociedades modernas, pelo contrário, a consciência coletiva se enfraquece. É esse enfraquecimento que favorece, para Durkheim, o desenvolvimento da divisão do trabalho. Mas se a sociedade resiste a esse enfraquecimento da consciência coletiva, é porque "a divisão do trabalho une ao mesmo tempo o que ela opõe". (DURKHEIM, 20I6, p. 259) Ela não é unívoca. Para Durkheim, ela "converge as atividades que diferencia; ela aproxima o que ela separa". (DURKHEIM, 20I6, p. 259) Durkheim então acrescenta um argumento decisivo. Ele enfatiza que "já que a competição não pode ter determinado essa reconciliação, ela deve ter preexistido; é necessário que os indivíduos, entre os quais a luta se engaja, já estejam solidários e o sintam, isto quer dizer, pertencendo à uma mesma sociedade". (DURKHEIM, 20I6, p. 259)

Durkheim mostra, então, que a divisão do trabalho "só pode se produzir dentro de uma sociedade pré-existente". (DURKHEIM, 20I6, p. 260) Esse autor (20I6, p. 260) entende por isso que é preciso primeiro "existir entre eles laços morais". O autor, portanto, nos convida a considerar que a sociedade é um pré-requisito para a divisão do trabalho e não o contrário. A demonstração é elegante: "A vida coletiva não nasce da vida individual, mas é, ao contrário, a segunda que nasce da primeira. É somente nessa condição que podemos explicar como a individualidade pessoal das unidades sociais foi capaz de se formar e crescer sem desintegrar a sociedade". (DURKHEIM, 20I6, p. 264) Isso remete à interpretação maussiana de Durkheim. (CEFAÏ; CHANIAL, 200o)

No entanto, a demonstração de Durkheim tropeça em um ponto. Ela supõe, de fato, ver na divisão do trabalho não apenas o aumento dos rendimentos das funções divididas, mas também o das solidariedades entre essas funções. Para Durkheim, qualquer ação produtiva pressupõe ao mesmo tempo uma diferenciação de tarefas pela divisão do trabalho e uma integração em um todo humano a fim de alcançar as finalidades coletivas. (LAVILLE, 20I7) 
O principal resultado da divisão do trabalho não é, portanto, na "esfera dos interesses econômicos, mas no estabelecimento de uma ordem social e moral sui generis. Indivíduos não são independentes, eles devem pactuar-se. A divisão do trabalho, longe de dividir os homens, reforça sua complementaridade para cooperar". (PAUGAM, 20I6, p. I5) Para isso, no entanto, uma condição é necessária, conforme o próprio Durkheim reconhece, a divisão do trabalho supõe que

\begin{abstract}
o trabalhador, longe de se inclinar sobre sua tarefa, não perde de vista seus colaboradores, age sobre eles e recebe sua ação. Portanto, não é uma máquina que repete movimentos cuja direção não percebe, mas sabe que eles tendem para qualquer parte, em direção a um objetivo que ele percebe mais ou menos distintamente. (DURKHEIM, 20I6, p. 365)
\end{abstract}

É aí que está o problema. Se o esquema proposto por Durkheim é particularmente relevante, ele se depara com realidades um pouco diferentes em campo. Em sua versão prosaica, a divisão do trabalho pode ajudar a secar a força integrativa solidária. Durkheim não se deixa enganar. Ele dedica a última parte do seu livro ao que ele chama de formas anormais. Ele admite que a "repetição dos mesmos movimentos com uma regularidade monótona tem o efeito de transformar o trabalhador em uma máquina inerte". (PAUGAM, 20I6, p. 25) Ele reconhece que os trabalhadores podem alimentar uma grande dose de amargura ao estarem submetidos a um sentimento de inferioridade permanante. Todo o desafio da demonstração de Durkheim é saber se essas formas que ele qualifica como anormais são excepcionais (ou não). Ora, o grau de excepcionalidade depende do direito social e das proteções e garantias coletivas que podem ser fornecidas pelo estado de bem-estar social. A questão da solidariedade no âmbito da divisão do trabalho leva, assim, incidentalmente às relações de regulação existentes entre o mercado e o Estado, mas também à possibilidade de uma outra economia. 


\section{Solidariedade e racionalidade}

Assim como Durkheim, Weber também retoma as categorias de Tönnies para distinguir duas formas essenciais para a análise sociológica: a comunalização, que ele julga ser guiada pelo sentimento subjetivo dos participantes de pertencimento à mesma comunidade; e a sociação, que ele define como uma relação social baseada em um compromisso de interesse motivado racionalmente. A comunalização pode se exprimir numa comunidade familiar, num grupo de amigos, mas também em uma nação. A sociação pode se traduzir em um livre acordo de troca no mercado, através da busca de interesses materiais, mas também através de uma associação baseada em convicção organizada para servir uma causa. No entanto, por trás dessa primeira proposta de classificação, Weber imediatamente observa que "a grande maioria das relações sociais tem em parte o caráter de uma comunalização e em parte aquele de uma sociação". (WEBER, I97I, p.79) Assim, a comunalização não está protegida contra as violências que poderiam ser expressas dentro dela, e a sociação, mesmo aquela mais fria que se possa imaginar, nunca está completamente livre de valores sentimentais.

Weber vê na burocracia um sistema racional e eficaz que impede os desvios dos responsáveis através da sua inclusão em um marco regulatório obrigatório. Assim, ele se refere à dominação legal-racional para invocar um sistema capaz de regular as práticas liberticidas potenciais do poder político. As regras formais apoiadas pela burocracia são de fato um remédio contra a arbitrariedade, que ao mesmo tempo condiciona a previsibilidade do comportamento administrativo. (CROZIER, I964) A burocracia tem, portanto, vantagens inegáveis. A figura do funcionário que "cumpre sua função sem influência de pessoas; formalmente, igualmente para todos, isto é, para todos os interessados na mesma situação de fato", coloca a burocratização na "sombra inseparável da democracia de massa". (WEBER, I97I, p. 30I)

Mas, ao mesmo tempo, Weber reconhece que a burocracia pode ter uma dimensão opressiva e resultar no que ele chama de "jaula de ferro", que aprisiona os indivíduos como uma armadilha e um fator de opressão. (WEBER, 1964) 
A burocracia repousa incidentalmente sobre "o conhecimento especializado cuja necessidade absoluta é determinada pela tecnologia moderna e pela economia da produção de bens". (WEBER, I97I, p. 298) Como tal, a burocracia está realmente no coração do crescimento do capitalismo e não se reduz à figura do funcionário. Se ele postula que o empreendedor capitalista é "a única instância realmente imune (pelo menos relativamente) contra a inevitabilidade da dominação burocrática racional do saber" (WEBER, 197I, p. 300), por outro lado, sublinha, ao mesmo tempo, como aponta Colliot-Thélène, que "as formas modernas de dominação compartilham com o sistema econômico capitalista o caráter de impessoalidade [...]. A fórmula sem levar em conta a pessoa é a palavra de ordem do mercado e é também a palavra de ordem da pura dominação burocrática". (COLLIOT-THÉLÈNE, 2OII, p. I8) De fato, lógicas comerciais e burocráticas se conjugam em torno de um mesmo desejo de implementar um esquema de gerenciamento centralizado baseado em uma abordagem padronizada. Este é vetor de um sistema de dominação e de um certo número de patologias. (SCOTT, 1998, p. 38) Longe de se opor ao mercado, a burocracia estaria, portanto, no coração de sua lógica de extensão. (GREABER, 2015, p. 4I) Isso sugere que as empresas comerciais não escapam à burocracia, contrariando as ideias comuns da ideologia liberal. Podemos, portanto, considerar que existem várias formas de burocracia.

Para distinguir as diferentes formas de burocracia - aquelas que protegem e aquelas que oprimem -, Weber nos dá a chave ao diferenciar dois tipos de racionalidade. A primeira que ele descreve como formalmente racional Zweckrationalität - se expressa em valores monetários por meio do raciocínio numérico ou contábil. (WEBER, 197I, p. I30) A segunda, que ele designa como racionalidade material - Wertrationalität -, não se apega ao aspecto formal, mas leva em conta outros requisitos: ético, político, utilitarista, hedonísticos, de classe ou igualitário. Essa segunda racionalidade se expressa em valor e é materialmente orientada para a finalidade. Devido à diversidade de motivos sobre os quais ela pode repousar, a racionalidade material é inerentemente plurivocal. (COLLIOT-THÉLÈNE, 2OII, p. I7) 
É interessante notar que o trabalho de Weber pertence a uma "sociologia compreensiva, já que o objeto do seu estudo é a ação humana, e que esta possui um significado". (MAZUIR, 2004, p. I22) Se sua abordagem está alinhada com seu tempo, ela não é verdadeiramente congruente com o conceito moderno de organização desenvolvido pela sociologia das organizações. (MAYNTZ, 1965) Para Weber, de fato, o agrupamento da própria dominação é "considerado no contexto de um todo maior, a saber, a ordem política e social de uma dada sociedade". (MAYNTZ, 1965, p. 7) Weber se interessa muito pouco pela eficiência organizacional. Ele está mais interessado nas características organizacionais ou processuais que determinam a atividade organizacional. Existe uma perspectiva interessante para a evolução do pensamento. Como Mayntz aponta, precisamos desenvolver "uma análise orientada de tal maneira que combine necessariamente o pensamento no nível organizacional com a reflexão no nível do conjunto da sociedade". (MAYNTZ, I965, p. 7) Além disso, o pensamento de Weber não se concentra apenas na lógica da dominação. Assim, para Weber, os agrupamentos também podem se esforçar para "reduzir os poderes de dominação relacionados às funções de execução" (WEBER, 197I, p. 376) A democracia direta sem dominação é possível nesses agrupamentos, desde que "os partidos não se estabeleçam como estruturas permanentes, não lutem entre si e não procurem se apropriar das funções. Caso contrário, o líder do partido que luta e triunfa - pouco importando os meios - se torna, com sua direção administrativa, um instrumento de dominação, apesar da manutenção de todas as formas da administração anterior". (WEBER, I97I, p. 379) Vemos aí que Weber prefigura a lei de ferro ${ }^{7}$ da oligarquia de Michels, um de seus alunos. (MICHELS, 20I5)

Weber qualifica como notáveis as pessoas com duas características: estar em uma situação econômica suficiente para permitir-lhes se engajar nas ações de associação sem contrapartida monetária na forma de salários e desfrutar de estima social propícia à confiança de outros membros. Weber

7 A lei de ferro é um argumeto de Michels que tende a demonstrar que as organizações têm tendência irredutível favorecendo a formação de uma oligarquia. 
aponta que "os notáveis podem viver para a política sem ter que viver dela", e que sua situação pressupõe "um grau específico de disponibilidade resultante de seus assuntos privados". (WEBER, I97I, p. 378) Por essas razões, Weber acredita que "toda democracia direta tende a se tornar uma administração de notáveis". Do ponto de vista ideal, pois estes são considerados especialmente qualificados pela experiência e objetividade. Do ponto de vista material, pois é pouco onerosa e, no limite, inteiramente gratuito. (WEBER, I97I, p. 378)

Se Weber salienta enfim que grupos pequenos têm mais capacidade de evitar os riscos da dominação interna, por outro lado, ele estima que grupos maiores também podem fazer isso com algumas precauções que ele enumera (WEBER, I97I, p. 377):

a. duração reduzida da função, tanto quanto possível num intervalo entre duas assembléias dos membros;

b. direito de chamada a qualquer momento;

c. princípio da mudança do papel ou saída da nomeação, de maneira que todos tenham sua vez uma vez; trata-se de evitar a posição de força própria do conhecimento especializado ou aquela que estaria ligada ao conhecimento dos segredos dos serviços oficiais;

d. mandato estritamente imperativo sobre o modo de gestão (competência concreta e não geral) estabelecido pela assembléia de membros;

e. obrigação estrita de reportar à assembleia dos membros;

f. obrigação de submeter a esta assembléia (ou a um comitê) toda questão imprevista e particular;

g. um grande número de postos secundários e munidos de missões especiais, daí o caráter de profissão auxiliar que possui a função.

Ao falar de grupos que buscam reduzir os poderes de dominação, Weber faz referência a um campo de saberes que se desenvolverá na França sob o nome de economia social. 


\section{A emergência da economia social}

A economia social tem seus teóricos. Léon Walras destaca-se entre todos os economistas quando ele afirma a existência de várias abordagens para a economia. Assim, ele distingue a economia pura, que é a ciência da "riqueza social considerada em si", a economia aplicada e a economia moral. (DOCKÈS, 2005, p. 8) Se essas três abordagens teóricas se referem a diferentes verdades, todas elas têm, no entanto, segundo ele, o caráter de ciência. Isso o leva a aproximar os atores humanos sob duas dimensões: homo economicus e homo ethicus. (WALRAS, 1992, p. 406) Como tal, a justiça é um critério "tão científico quanto o critério de eficiência para a produção ou quanto a verdade econômica pura para a teoria dos preços". (LALLEMENT 20I2, p. 63) Walras fornece, assim, o que ele considera ser "a sociedade racional que se realiza e que se apresenta como uma conciliação entre o justo e o útil". (DOCKÈS, 2005, p. I8) Walras enfatiza a dinâmica das forças produtivas. Ele se mostra idealista quando observa que "o vapor e as máquinas fizeram desaparecer a escravidão e a servidão" e que "a indústria moderna fará desaparecer as injustiças". (DOCKÈS, 2005, p. 19) No entanto, o homem walrasiano é caracterizado por "três grandes faculdades psicológicas que são a sensibilidade, a inteligência e a vontade". (LACAN, 2006, p. 72)

Isso o leva a considerar a questão da pobreza de maneira radical diante de outros economistas. Segundo ele, se há pessoas pobres, é por causa de uma "distribuição inicial injusta da riqueza social entre os indivíduos, o que contradiz a igualdade de condições". (LALLEMENT, 20I2, p. 58) Deve-se, portanto, intervir nesta distribuição inicial. Ele propõe que a terra "não pode ser propriedade privada porque pertence, segundo ele, à humanidade e, portanto, não pode ser objeto de uma apropriação privada". (DOCKÈS, 2005, p. 57) Além disso, Walras estava convencido do interesse de sociedades mutualistas de seguros. Ele observou que, sem buscar nenhum lucro, elas asseguram a seus membros uma cobertura de risco com base na reciprocidade e em uma estrutura livre e opcional. (LALLEMENT, 2012, p. 59) 
Charles Gide se inscreve na vizinhança intelectual de Walras. Assim como este último, ele recusa a concorrência como um princípio suficiente para pensar sobre a organização da vida econômica. (GIDE, 20Io) Como Walras, ele pensa que a resolução do problema social "consiste em conciliar a justiça com a liberdade". (PÉNIN, 2006, p. 78) Ele insiste sobre a solidariedade e a cooperação que lhe parecem os princípios fundamentais da abordagem econômica. (PÉNIN, 2006, p. 76) Para Gide, a solidariedade e a cooperação se concretizam na associação profissional, na associação mutualista e na cooperativa de consumo - da qual ele é um especialista. Gide destaca "as instituições de economia social que ele queria ver desenvolvidas". (PÉNIN, 2006, p. 80) Nisso, ele se inscreve na esteira dos trabalhos de Léon Bourgeois e visa uma superação da solidariedade natural.

\section{A inovação organizacional da economia social}

Se no campo das ideias as obras de Walras e Gide movem as bases do pensamento, é no campo da ação que aparecem as inovações e dão uma tradução prática dos benefícios de uma economia moral guiada pelo senso de justiça. Os componentes fundamentais da economia social são as cooperativas, as organizações mutualistas e as associações com vocação gestionária. (VIENNEY, 1994) Como ressalta Musso, a problematização da solidariedade "emerge com a revolução industrial que, por um lado, atribui a cada um o seu lugar na fábrica pela divisão do trabalho e, por outro, gera o pauperismo e a exclusão". (MUSSO, 2015, p. 94-95) Se pudermos remontar as fontes de inspiração da mutualidade até as camaradarias - campagnonnages - e corporações de ofício do Antigo Regime, seu crescimento é contemporâneo ao século XIX. A mutualidade conseguiu emergir em um contexto jurídico muito desfavorável herdado da Revolução Francesa e dos códigos napoleônicos. (LABORDE, 2015, p. III) Embora "o termo solidariedade não entre no vocabulário comum do mundo mutualista antes do final do século XIX" (TOUCAS-TRUYEN, 2OI4, p. 98), são de fato as mutualidades que o traduzirão em realidade através de múltiplas experiências. Estas assumem formas diferentes, "da simples técnica de seguro 
neutra à demonstração coletiva de compaixão no funeral dos membros". (TOUCAS-TRUYEN, 20I4, p. 98) Para além dos mecanismos concretos de solidariedade econômica, os membros "tecem laços de fraternidade entre eles de acordo com o termo consagrado nos escritos mutualistas". (TOUCAS-TRUYEN, 2OI4, p. 98) Se as mutualidades se concentram na solidariedade redistributiva (TOUCAS-TRUYEN, 2OI4), a forma cooperativa pretende dar o mesmo poder de gestão ao empregado e ao aportador de capitais.

Embora no centro do nascimento das organizações de economia social, as técnicas de gestão foram pouco estudadas como tal na área das ciências da gestão. No entanto, sem a implementação de métodos organizacionais inovadores, as primeiras iniciativas de cooperativas e organizações mutualistas não teriam sido capazes de lidar com o contexto muito difícil em que surgiram. A experiência pioneira de Rochdale, no início do século XIX, é ilustrativa dessa capacidade. Desde o início, a experiência coloca o princípio da dupla qualidade dos atores. Isso significa que os beneficiários também são membros. A ambição é grande e a complexidade da gestão elevada.

Segundo esse princípio, essa primeira cooperativa de consumo teria que combinar um sistema centralizado e coletivo de gestão de compras com um sistema de governança capaz de garantir a tomada de decisões democráticas e a redistribuição equitativa dos excedentes. O sucesso do lançamento das primeiras experiências coletivas dos trabalhadores estava, portanto, ligados ao engajamento sem falhas dos atores. Os trabalhadores que os iniciaram eram de fato novatos em termos de sua competência gerencial. Em primeiro lugar, eles tiveram que pôr a invenção à prova. Posteriormente, a durabilidade e disseminação dessas experiências foram os resultados de um longo processo de melhoria das práticas. (TOUCAS-TRUYEN, 2OI4)

A grande diversidade de formas de cooperativas - agrícola, financeira, de produção, de consumo etc. - que dela resultam reflete a pertinência e a força da proposição organizacional. Essa diversidade também foi ao mesmo tempo um convite para comparação. Assim, Lassale estabeleceu em I893 uma hierarquia entre cooperativas de produção e cooperativas de consumo. Para ele, "a exploração de que os trabalhadores são vítimas, afetam a eles como produ- 
tores e não como consumidores. É, portanto, sob o regime de produção que devemos agir, se realmente queremos melhorar seu destino". (LASSALE, I893, p. 409) Por trás desse debate entre diferentes formas de cooperação se esconde de fato um outro: o da oposição entre cooperativas neutras e cooperativas socialistas. (VANDERVELDE, I9I3) As primeiras eram aquelas que tendiam a ver a cooperativa como um negócio. As segundas eram cooperativas que se percebiam "como instrumento de combate, como meio de emancipação". (VANDERVELDE, I9I3, p. 79) Assim, a experiência cooperativista concede "ao trabalhador inteligente os meios para criar capital e aprender o manejo dos negócios comerciais, permitindo se emancipar do patronato". (AUDIER, 20IO, p. 45) Por um lado, essa oposição nos leva a considerar uma origem pluralista da economia social que combina influência liberal, os valores do cristianismo social e a ascendência socialista. (PARODI, 2008) Ela também revela contradições iniciais acontecendo na definição e na natureza do projeto cooperativo.

\section{A profissionalização gestionária das cooperativas}

As cooperativas se distinguem das associações, que não possuem acionistas. No entanto, é importante notar que a gestão é considerada como um forte critério de pertencimento à economia social. Assim, as associações que pertencem à economia social são aquelas que são "gestionárias". Isso significa que suas necessidades de gestão se mostram, em particular, pela presença de assalariados no seu seio - como nas cooperativas. Ao mesmo tempo, as associações têm um poder de atração sobre as cooperativas, e é possível considerar a cooperativa como "a combinação de uma associação e uma empresa". (LAVILLE 20Io, p. 293) Isso abre um leque de possibilidades em formas infinitamente variadas (DRAPERI, 1998) em que o empreendedorismo coletivo desempenha um papel importante. (DEMOUSTIER; ROUSSELIÈRE; CLERC; CASSIER, 2003) No entanto, podemos nos perguntar qual é a natureza e o propósito dessa gestão coletiva? Deveria servir aos mais fracos trabalhando pela transformação do campo econômico - como sugere a ambição emancipatória das cooperativas? Deveria, pelo contrário, privilegiar a perenidade de empregos e da organização através de 
uma melhor integração na economia de mercado? A resposta a dar não é óbvia porque põe em tensão os atores do quadrilátero de Desroche (1994): acionistas, administradores, gerentes e empregados.

As velhas organizações que se reconhecem "na economia social pela conjunção de seu status cooperativo, mutualista ou associativo e sua função gerencial [...] vivem contradições que distanciam algumas delas das formas de democracia e solidariedade". (DEMOUSTIER; ROUSSELIÈRE; CLERC; CASSIER, 2003, p. 56) A partir da década de I970, a intensidade capitalística aumentou. Ao mesmo tempo, a generalização das práticas de cooptação garantiu aos gestores das cooperativas a quase ausência de contrapoderes. A integração econômica no mercado - garantia para essas cooperativas de uma capacidade de resistência diante da concorrência - induzia, ao mesmo tempo, uma deriva com a adoção de normas e práticas de gestão provenientes do mundo mercantil.

Essa evolução torna-se ainda mais forte pois a legislação nacional e europeia promove a livre concorrência e, consequentemente, o gradual alinhamento das regras das cooperativas com as das empresas. Como resultado, a diferença estatutária nas cooperativas tende a se atenuar e o sentimento de pertencer à economia social vai se desintegrando. Isso dificulta a manutenção do duplo caráter e leva as cooperativas a favorecerem a lógica da empresa em detrimento da lógica associativa. No setor financeiro e de seguros, grandes cooperativas se abrem para investidores não cooperados, enquanto outras criam subsidiárias mercantis. A importação das ferramentas e métodos de gestão das empresas mercantis participa, assim, de um trabalho de aculturação. Os funcionários dessas organizações não percebem mais em seu trabalho diário os efeitos da diferença estatutária. Eles não se reconhecem mais como atores da economia social e solidária.

\section{Gestão e reconhecimento}

A questão do reconhecimento é um tema de importância primordial. Axel Honneth entendeu particularmente os desafios. Esse autor coloca no centro de sua análise social a necessidade dos homens se beneficiarem de for- 
mas de reconhecimento. (HONNETH, 2000) Ele postula que o "eu" é formado na aprovação dos outros. Honneth distingue três formas de reconhecimento: a solicitude pessoal que se relaciona com afetos e amor; a consideração cognitiva que se abre à responsabilidade moral e supõe relações jurídicas; e a estima social que se manifesta em uma comunidade de valor. Como o espaço social é marcado pelo conflito, o conceito de reconhecimento é, portanto, inseparável de uma luta em que cada um tenta garantir o acesso à estima. Como existem três formas de reconhecimento, essa luta "leva do amor ao direito e do direito à solidariedade". (COURTEL, 2OIO, p. II)

Para Honneth, o termo "solidariedade" refere-se primeiro a "uma espécie de relação de interação em que os sujeitos estão interessados nos itinerários pessoais entre si, porque entre eles estabeleceram vínculos de estima simétricos". (HONNETH, 2000, p. I56) É na relação intersubjetiva que se coloca a questão do reconhecimento. A solidariedade está presente enquanto houver uma comunidade ética que permita compartilhar por fora do amor e do direito uma estima recíproca. A solidariedade só é possível para Honneth se as relações de estima cruzada se desenvolverem entre os indivíduos e se essa simpatia primeira se traduza em atos que prolongam esse sentimento. A solidariedade pode, portanto, ser interpretada como uma forma de reconhecimento. É um ato performativo de confirmação pelo outro das qualidades morais que os indivíduos emprestam uns aos outros. Portanto, atenção à solidariedade é uma atenção às identidades e feridas que podem resultar em um déficit - ou negação - de reconhecimento. Quando se trata de gestão, a análise de Honneth coloca a autoestima no centro da prevenção de conflitos. Ele se refere à preservação de identidades e de saberes ancestrais.

\section{Gestão do bem viver e pensamento anticolonial}

Uma renovação política foi expressa nos países andinos com o advento de constituições conferindo direitos à natureza e integrando as noções de buen vivir no Equador (ACOSTA, 20I4) e bien vivir na Bolívia. (MARTINS, 20I4) Essas noções são "as traduções espanholas de sumak kawsay ou suma 
qamaña". (CADALEN, 20I8, p. 79) Os índios da Bolívia consideram que a terra é uma Pasha Mama, "madre tierra ou mãe terra, a única legítima para fundar o ideal coletivo do bien vivir". (MARTINS, 20I4, p. 77) A utopia da Pacha Mama se distingue de uma visão utilitarista ancorada na apropriação privada e no uso egoísta para uma visão antiutilitária de bem viver, pois ela "valoriza o bem-estar coletivo". (MARTINS, 20I4, p. 79) Viver bem nos convida a compreender "os limites de um modelo de dominação baseado na lógica privada" e a opor-se "à apropriação das riquezas materiais por um grupo restrito em detrimento da maioria". (MARTINS, 20I4, p. 80)

A contribuição política da Pacha Mama reside "na originalidade de uma contestação pós-colonial levada por um movimento social indígena que foi capaz de reverter o colonialismo para reintroduzir o poder da tradição étnica na cosmologia ocidental". (MARTINS, 20I4, p. 80) A abordagem ambiental do bem viver faz parte das práticas dos Ameríndios. Observa-se que a relação entre homem e natureza na Amazônia "repousa sempre na noção de dádiva, o que revela uma importante ecologia cultural". 8 (VIVEIROS DE CASTRO, 2002, p. 327) Os Ameríndios "buscam ritualizar cada corte de árvores e [...] se sentem obrigados, pela força da contra-dádiva, a plantar outra árvore para restabelecer o equilíbrio perdido". (MARTINS, 20I4, p. 80) Os pacha-mamistas bolivianos consideram que os "recursos vitais existiam muito antes da chegada dos colonizadores, das empresas privadas, dos políticos de etnia branca, bem antes do próprio homem, e que elas sempre constituem a base de sua sobrevivência material e espiritual". (MARTINS, 20I4, p. 82) Reside aqui uma metáfora ou um "símbolo que dá sentido aos movimentos coletivos" e que é "a palavra de ordem contra a apropriação privada das condições coletivas da vida comunitária". (MARTINS, 20I4, p. 83) É interessante notar que o bem viver inspira uma nova hierarquia postulando que os direitos à vida "são fundamentais e universais pois eles são compartilhados por todos os seres vivos e que os direitos capitalistas ao crescimento e à acumulação são direitos privados que não são universais,

8 Citado e traduzido por Martins (2014). 
são direitos menores". (MARTINS, 20I4, p. 84) Desse modo, a economia de mercado é reintegrada no social. Nesse sentido, o bem viver é uma crítica à ideia de crescimento econômico ilimitado. (MARTINS, 2OI4; GADREY, 2OIO) A ideia de bem viver é "uma constatação anticapitalista e comunitária que busca valorizar a riqueza fora da lógica da acumulação, do individualismo e do etnocentrismo". (FARAH; GIL, 2OI2, p. IOO)

\section{Gestão e economia popular}

Nos países do norte, estatutos organizativos como cooperativas, organizações mutualistas e associações têm constituído formas de resistências ao capitalismo e à sua ponta de lança, a empresa privada. Nos países do sul - e especialmente na América Latina -, a relação entre solidariedade e organizações tem sido diferente. A resistência veio das camadas sociais mais excluídas dos processos de desenvolvimento. Ela se exprime pelas manifestações relacionadas aos modos de organização das comunidades tradicionais. À contribuição dos povos ancestrais de origem indígena veio adicionar-se a resistência das comunidades de antigos escravos e seus descendentes. Na periferia das grandes cidades, onde essas populações foram relegadas, múltiplas estratégias são seguidas pelas famílias na luta pela sobrevivência. Para analisar a gestão da solidariedade dentro dessas comunidades, devemos primeiro entender como as redes de cooperação são formadas e como se constroem os itinerários de vida e os percursos profissionais individuais.

Uma primeira luz pode ser colocada sobre a relação entre solidariedade e organização nos países do sul usando a noção de economia popular. Ela permite articular o estudo da vida social à organização do trabalho e identificar uma realidade heterogênea caracterizada pelo surgimento e multiplicação de numerosas pequenas atividades produtivas e comerciais nos setores pobres e marginais das grandes cidades da América Latina. (RAZETO, I99I) Essa realidade pode assumir a forma de pequenos ofícios, profissões autônomas, microempresas ou associações. A economia popular extrai sua força da constituição de um conjunto de relações de reciprocidade tecidas no 
exercício dessas múltiplas atividades. Este conjunto constitui uma extensão das solidariedades ordinárias da vida cotidiana, quer sejam familiares, de vizinhança ou de amizade. O trabalho realizado no contexto da economia popular é frequentemente realizado no espaço familiar. (KRAYCHETTE; LARA; COSTA, 2000) Se a economia popular compartilha com a economia informal uma resposta ao problema do desemprego através da lógica da sobrevivência em áreas urbanas (LAUTIER, 1994), ela se diferencia por suas fortes raízes locais em uma base social e de saberes ancestrais. A economia popular propõe, assim, uma articulação específica entre as necessidades e as competências disponíveis no nível local. (FRANÇA FILHO, 2002) Essa articulação pode ser ilustrada no caso brasileiro através dos muito conhecidos exemplos de mutirão. Enquanto um sistema auto-organizado de base popular e comunitária, o mutirão consiste em mobilizar e associar o conjunto dos membros de uma comunidade na execução de um projeto. (FRANÇA FILHO, 2002)

Embora as atividades da economia popular desempenhem um papel importante no cotidiano das populações excluídas, elas têm pouca capacidade de se traduzir em mudanças institucionais. Portanto, a ideia de construir uma Economia Popular e Solidária (EPS) aparece como uma estratégia de organização virtuosa para a emancipação das camadas populares. (FRANÇA FILHO, 2006a) O objetivo da EPS é passar de uma lógica de sobrevivência para uma lógica de transformação social capaz de melhorar o cotidiano das pessoas excluídas. (CORAGGIO, 2004) Assim, os fundamentos da solidariedade presentes nas práticas da economia popular acabam constituindo as bases necessárias para a invenção de novas formas de auto-organização socioeconômica e de novos marcos para as políticas públicas. (FRANÇA FILHO, 2006b)

Uma segunda perspectiva de reflexão relativa à solidariedade baseia-se na análise de histórias de vida indicando como os sujeitos encaram e transpõem os muros da desigualdade. O estudo dos percursos de mobilidade social ascendentes de pessoas nas condições mais desfavoráveis permite compreender a natureza das redes de solidariedade. Essas redes são complexas e combinam relações entre próximos - família extensa, relações de amizade, co- 
nhecidos - e relações construídas dentro de organizações solidárias. Embora essas organizações sempre tenham desempenhado um papel fundamental na história das solidariedades voltada aos mais pobres, elas são pouco conhecidas no campo das ciências da gestão. Dois tipos de organizações baseadas na tradição do povo negro brasileiro são importantes para estudar: os terreiros e as irmandades. Os terreiros são organizações administradas por comunidades religiosas tradicionais do candomblé - cuja origem é africana. Essas organizações desempenharam um papel importante nos meios populares. Elas apareceram entre o final do século XIX e o começo do século XX, por iniciativa de ex-escravos que procuravam fornecer espaços que acolhessem vítimas de discriminação. Como um local de solidariedade, essas organizações promoveram o apoio social e a reinserção de pessoas excluídas.

Na cidade de Salvador, um terreiro chamado Tumba Junsara está atualmente passando por um processo de reconhecimento institucional para incluí-lo no patrimônio cultural da cidade. Esse terreiro se definiu como sendo uma Milonga. Esta palavra originada da língua do povo Banto significa mistura. A organização se vê, portanto, como o resultado de uma mistura de todos os elementos culturais da nação brasileira. Esse terreiro reconhece assim a tradição baseada no Candomblé de Angola, a tradição do Banto, além da Iorubá, Jêje e Ijexá, mas também as culturas indígenas, entre outras. Os Terreiros ajudaram a recriar formas fortes de solidariedade para populações reduzidas à escravidão e separadas de suas famílias, seus clãs e suas tribos.

As irmandades são de dois tipos: irmandades negras laicas e irmandades negras religiosas. As primeiras são sociedades laicas dedicadas à gestão da proteção social dos portadores de deficiência - sociedade protetora dos desvalidos -, que surgiram durante a abolição da escravatura em I888 em várias regiões do Brasil - Bahia, Minas Gerais, Rio de Janeiro etc. No início, as organizações assumiram a compra das auforrias, títulos que permitiam o acesso ao direito de cidadãos para ex-escravos. Posteriormente, a sua missão evoluiu rapidamente para o campo da formação, da educação técnica e da inserção profissional. No início do século XX, essas organizações foram os principais 
atores da profissionalização dos jovens das classes populares, formando-os para os ofícios da construção - pedreiros, carpinteiros, ferreiros etc. Em um período em que a escola pública praticamente não era acessível para os descendentes de escravos, as irmandades negras laicas desempenharam um papel de fundamental importância na melhoria das condições de vida dos negros no Brasil. As segundas são organizações religiosas que agrupam populações católicas de origem africana. Na Bahia, essas organizações oferecem abrigos para as pessoas mais discriminadas, como mães solteiras.

\section{Da prática aos ideais: a solidariedade no pensamento crítico brasileiro}

A solidariedade é um elemento forte entre alguns intelectuais brasileiros e três nomes de grande importância merecem ser mencionados: o educador e filósofo Paulo Freire, o geógrafo Milton Santos e o sociólogo Alberto Guerreiro Ramos. Freire nasceu em I9 de setembro de I92I, na cidade de Recife. Sua família era de classe média, mas ele experimentou a pobreza durante a crise de 1929. O trabalho de Freire se inscreve no campo das teorias da educação. Sua obra consistiu em desenvolver métodos de ensino para os mais pobres, introduzindo métodos inovadores de alfabetização. Durante a ditadura militar no Brasil, ele foi perseguido, acusado de subversão e condenado ao exílio, isso o levou a trabalhar no Chile durante cinco anos no Instituto Chileno de Reforma Agrária. Foi durante esse período que ele escreveu sua obra principal Pedagogia do Oprimido, publicada em I968. Já em I969, Freire lecionou na Universidade de Harvard, nos Estados Unidos, e se tornou, na década seguinte, consultor do Conselho Mundial de Igrejas (CMI) em Genebra. Ele forneceu assistência pedagógica a numerosos países africanos pobres no início de sua independência. Após ter passado I6 anos no exílio, retornou ao Brasil em I980 e escreveu dois dos livros fundamentais de sua obra: Pedagogia da Esperança (1992) e À sombra desta mangueira (1995). Freire enfatiza a dialogicidade e seu papel central no processo de educação. Para Freire, a aprendizagem se desenrola num processo em que os atores devem alternar suas posturas: ora como 
educadores, ora como educandos. Trata-se de aprender com a experiência de vida do outro. O tema da solidariedade está subjacente em toda sua obra, tornando-se explícito em um dos seus últimos livros, denominado Pedagogia da solidariedade. (FREIRE; FERREIRA DE OLIVEIRA; FREIRE, 2009) Nesse trabalho, Freire defende uma educação libertária e reafirma a necessidade da solidariedade como a condição de um mundo mais democrático.

Milton Santos é um geógrafo negro brasileiro nascido em 3 de maio de I926 na cidade de Brotas de Macaúba, no estado da Bahia. Ele obteve seu doutorado em Geografia na Universidade de Estrasburgo, na França. No final dos anos I950, retornou ao Brasil e criou o Laboratório de Estudos Regionais. Com o golpe militar, ele retornou à França, onde se tornou professor universitário. Em I977, Santos voltou ao Brasil e ensinou geografia humana na Universidade Federal do Rio de Janeiro (UFRJ). Em I994, ele recebeu o Prêmio Internacional de Geografia Vautrin-Lud. Milton Santos desenvolveu uma abordagem crítica do ambiente urbano em que denuncia as condições de vida na periferia das cidades e defende a solidariedade como um elemento central. Segundo ele, a solidariedade permite acompanhar na cidade o processo de cidadania democrática e combater o que ele chama de cidadania mutilada. (SANTOS, I993)

Guerreiro Ramos foi um sociólogo e político negro brasileiro. Ele nasceu em I3 de setembro de 1915 em Santo Amaro da Purificação, no estado da Bahia. Ele é considerado uma figura importante das ciências sociais no Brasil. Sua carreira intelectual - uma dúzia de livros e muitos artigos publicados em vários idiomas - soma-se a outras experiências: foi deputado federal do Rio de Janeiro e membro da delegação brasileira na Organização da Nações Unidas (ONU). Terminou sua carreira acadêmica como professor na Universidade da Califórnia e morreu em Los Angeles em 1982. Nos estudos recentes sobre seu trabalho, Guerreiro Ramos é descrito como "intelectual periférico". (MAIA, 2015) Três razões explicam essa qualificação, primeiro, Guerreiro Ramos se engajou como autor brasileiro em um diálogo crítico com as teorias sociológicas e filosóficas europeias e norte-americanas. Então, seu estilo de escrita se distingue pela recusa em se submeter aos cânones linguísticos do seu tem- 
po. Em suma, a obra de Guerreiro Ramos é animada por uma forte busca pela autonomia intelectual. Segundo Lynch (2015), Guerreiro Ramos desenvolve uma teoria pós-colonial na qual ele afirma uma posição crítica no campo das ciências sociais. Para Guerreiro Ramos, a solidariedade está implícita. Pode-se deduzir da importância que ele dá em sua obra a noção de "comunidade humana universal". (FLORES, 20I5) Trata-se, segundo ele, de um conceito central para uma cultura de direitos humanos no Brasil. Segundo Flores (2015), o conceito de comunidade humana universal está no coração do pensamento organizacional de Guerreiro Ramos e a gestão aparece como uma alavanca para a democracia substantiva e a governança cidadã. A ênfase de Guerreiro Ramos na racionalidade substantiva está alinhada com seu desejo de refundar a teoria organizacional e com sua preocupação de restaurar um significado da solidariedade no agir organizacional.

\section{REFAZER A HISTÓRIA DA GESTÃO A PARTIR DE UMA PERSPECTIVA SOLIDÁRIA}

Como vimos neste capítulo, a história da gestão evidencia inúmeros "encontros não acontecidos". A gestão parece ter fracassado em responder às demandas por transformação social. Importantes atores políticos que desejavam implementar políticas econômicas solidárias buscavam dentro dos métodos de gestão soluções operacionais sem encontrar o que esperavam. Esse foi o caso de Roosevelt nos Estados Unidos na época da aproximação sem amanhã entre Pinchot e Taylor. Esse também foi o caso na França, com Herriot, que prefaciou o livro de Casson sobre as ciências dos negócios. (NIKTIN, 2003) Nessa ocasião, Herriot adotou a ideia de que "os negócios devem ser dirigidos por uma ciência genuína, cujas leis devem ser descobertas pouco a pouco". (NIKTIN, 2003, p. 7I) Mas qual é essa ciência? Quais princípios a guiam? Em que a solidariedade pode construir uma melhor compreensão da ação coletiva?

A fama que beneficiou o trabalho de Taylor jogou nas sombras os autores que não participam dessa visão. A América triunfante de Taylor inventa o management e se autoriza a não retomar a longa história europeia ou das 
culturas ancestrais sobre a gestão. Sem piedade, ela negligencia as reflexões e experiências de organizações da economia social. A popularidade do gerenciamento científico de Taylor marginaliza os gestores do velho mundo. Para atingir seus objetivos, a administração nascente se veste das roupas da cientificidade. É a gestão "científica" que reduz ao silêncio os autores solidários. Esse ataque é duplo e vem de pensadores de mercado e escritores marxistas. Engels também estabelece uma diferença conceitual entre o socialismo científico e o socialismo utópico. (ENGELS, I950)

Assim, sob o pretexto da cientificidade, os autores liberais e marxistas buscam desqualificar a corrente solidarista. A escola solidária difere da "escola liberal na medida em que repudia o princípio da concorrência e da luta pela vida, substituindo-o pelo da cooperação e da união entre os interesses opostos" e se separa da escola revolucionária "na medida em que não acredita na eficácia da revolução e da expropriação para transformar o homem". (AUDIER, 20Io, p. 68) Na ausência da visão solidária, a gestão formal é colocada a serviço da moralização da economia no sentido de Thompson (1988), ou seja, de "preencher o vazio ético do capitalismo a partir do momento em que este se dissociava da ética protestante que fundou sua legitimidade". (GAULEJAC, 2005, p. 40) A consequência disso foi que a análise organizacional se desenvolveu a partir de uma perspectiva funcionalista. Como o funcionalismo é uma teoria "que tende a relacionar os fenômenos sociais às funções que eles asseguram" (GAULEJAC, 2005, p. 73), a economia política se transformou em "uma economia gerencial na qual as considerações contábeis e financeiras prevalecem sobre as considerações humanas e sociais". (GAULEJAC, 2005, p. 25) Torna-se necessário hoje que os laços entre história e gestão sejam desenvolvidos numa perspectiva crítica. (CAILLUET; LEMARCHAND; CHESSEL, 20I3) Cabe à administração se inclinar sobre os autores importantes e esquecidos de sua história para reabrir perspectivas de pensamento indispensáveis à reflexão sobre a sustentabilidade de nossos sistemas econômicos.

Ao nos interessarmos pela narrativa de uma contra-história da administração, destacamos autores que nos parecem úteis para repensar a gestão. 
Leroux nos ajuda, assim, a re-situar a solidariedade em relação à liberdade econômica do mercado e à igualdade defendida pelo Estado republicano diante de seus cidadãos. Com a ideia de um quase contrato, Bourgeois recoloca a equação solidária numa perspectiva organizacional e transgeracional. Tocqueville propõe a resolução de tensões entre os indivíduos e o coletivo pela democracia no seio das organizações guiadas pelo princípio do interesse bem compreendido. Tönnies e Durkheim repensam a divisão do trabalho por uma dupla caracterização da solidariedade. Weber considera várias formas de racionalidade. Walras e Gide estabelecem os princípios de uma economia aberta à solidariedade pois influenciada pela noção de justiça. Honneth mostra que a solidariedade é construída sobre o reconhecimento. Freire nos convida a levar em conta a questão educacional em uma perspectiva de emancipação. Os pacha-mamistas nos remete aos saberes organizacionais ancestrais que abre o caminho para o bem viver. Finalmente, Guerreiro Ramos avança o conceito de comunidade humana universal para pensar a solidariedade no campo do pensamento organizacional fora da dominação colonial.

Apesar das perspectivas abertas através de todos esses autores, vale a pena notar as tensões não resolvidas. A falta de um quadro teórico reconhecido para a gestão solidária tem sem dúvida autorizado uma deriva nas organizações que reivindicam a economia social e solidária. De fato, a adoção de uma gestão empresarial comercial e seus instrumentos usuais introduziram nessas organizações uma tecnologia invisível no sentido de Berry (1983). Esta agia como um cavalo de Tróia: deslizando de maneira insidiosa e progressiva, ela moveu por dentro o cursor da solidariedade para o da lógica de mercado. Não há quebra abrupta do pacto social, mas as ferramentas operaram uma mudança "profunda das representações da questão social e dos meios legítimos e necessários de lidar com ela". (CHAUVIÈRE, 2007, p. I4) Podemos nos perguntar com Bonnafous-Boucher em que medida a firma - e sua gestão -, enquanto objeto estabilizado, não bloqueia o pensamento organizacional? Para esta autora, é melhor falar de "teorias da organização do que de uma teoria das organizações". (BONNAFOUS-BOUCHER, 2005, p. 108) Nos parece 
preferível subscrever tal ideia: em vez de construir um modelo de gestão dominante que termina por se impor a todas as organizações - incluindo as que não reivindicam o mercado -, não é melhor pensar nos modelos concorrentes que podem ser adotados pelo conjunto das organizações? Uma tal proposição equivale a reverter a ordem dos valores. Em vez de defender a generalização do modelo genérico das empresas de mercado e sua adaptação às organizações da Economia Social e Solidária (ESS), não podemos produzir um modelo de gestão intrinsecamente solidário? Ele deveria, por definição, ser perfeitamente adequado às organizações de ESS, mas também pode ser adequado a organizações de mercado que buscam se libertar, como no exemplo das "empresas liberadas" na França. (PETERS, I993) Não devemos esquecer que gerir é também "inventar novos sistemas de legitimidade" (DAVID; HATCHUEL; LAUFER, 20I2, p. I7) e que as doutrinas da administração "tornam possível a reflexividade, portanto, a evolução dessa ação". (DAVID; HATCHUEL; LAUFER, 20I2, p. 33)

Essa inversão do quadro de pensamento pode ser traduzida, para os autores da gestão, em um ponto de grande virada na sociedade. Portanto, "os fenômenos organizacionais não são mais considerados como objetos autônomos em uma dada sociedade, eles fundam a sociedade". (DE VAUJANY; HUSSENOT; CHANLAT, 20I6, p. 20) O ponto de virada da sociedade nos questiona "sobre a emergência de fenômenos organizacionais e suas relações indissociáveis com as dinâmicas sócio-econômicas e ambientais que participam da construção da sociedade". (DE VAUJANY; HUSSENOT; CHANLAT, 20I6, p. I4) Três proposições podem assim ser anunciadas. Em primeiro lugar, a organização é um movimento permanente, o que significa que ela não pode ser "circunscrita dentro de um espaço preciso ou pelos contratos que unem as pessoas umas com os outras". (DE VAUJANY; HUSSENOT; CHANLAT, 20I6, p. I5) Nesse caso, a organização no sentido clássico se dissolve em favor de um contexto organizacional portador de potencialidades. "A organização é então um lugar aberto que pode incluir diferentes partes interessadas sem restrição a priori" (DE VAUJANY; HUSSENOT; CHANLAT, 20I6, p. I4) e sensível ao significado que é dado à ação 
coletiva. Em segundo lugar, a organização é um sistema situado, o que significa que é inseparável da dimensão material, espacial, temporal e cultural. Finalmente, a organização é um fenômeno heterogêneo feito de atores e artefatos que interagem. (DE VAUJANY; HUSSENOT; CHANLAT, 20I6) Com esses princípios e pressupostos, é possível pensar a transformação social no seio das organizações e considerar maneiras de reorganizar a solidariedade. 